\section{Pacific Northwest}

National Laboratory

Operated by Battelle for the

U.S. Department of Energy

\title{
Second Quarter Hanford Seismic Report for Fiscal Year 2003
}

PNNL Seismic Monitoring Team

D. C. Hartshorn

S. P. Reidel

A. C. Rohay

April 2003

Prepared for the U.S. Department of Energy

under Contract DE-AC06-76RL01830 


\title{
DISCLAIMER
}

This report was prepared as an account of work sponsored by an agency of the United States Government. Reference herein to any specific commercial product, process, or service by trade name, trademark, manufacturer, or otherwise does not necessarily constitute or imply its endorsement, recommendation, or favoring by the United States Government or any agency thereof, or Battelle Memorial Institute.

\author{
PACIFIC NORTHWEST NATIONAL LABORATORY \\ operated by \\ BATTELLE \\ for the \\ UNITED STATES DEPARTMENT OF ENERGY \\ under Contract DE-AC06-76RL01830
}

\begin{abstract}
Printed in the United States of America
Available to DOE and DOE contractors from the

Office of Scientific and Technical Information, P.O. Box 62, Oak Ridge, TN 37831:

prices available from (615) 576-8401.

Available to the public from the National Technical Information Service, U.S. Department of Commerce, 5285 Port Royal Rd., Springfield, VA 22161
\end{abstract}




\section{Second Quarter Hanford Seismic Report for Fiscal Year 2003}

Pacific Northwest National Laboratory Seismic Monitoring Team

D. C. Hartshorn

S. P. Reidel

A. C. Rohay

April 2003

Prepared for

the U.S. Department of Energy

under Contract DE-AC06-76RLO 1830

Pacific Northwest National Laboratory

Richland, Washington 99352 


\section{Summary}

Hanford Seismic Monitoring provides an uninterrupted collection of high-quality raw and processed seismic data from the Hanford Seismic Network for the U.S. Department of Energy and its contractors. Hanford Seismic Monitoring also locates and identifies sources of seismic activity and monitors changes in the historical pattern of seismic activity at the Hanford Site. The data are compiled, archived, and published for use by the Hanford Site for waste management, Natural Phenomena Hazards assessments, and engineering design and construction. In addition, the seismic monitoring organization works with the Hanford Site Emergency Services Organization to provide assistance in the event of a significant earthquake on the Hanford Site.

The Hanford Seismic Network and the Eastern Washington Regional Network consist of 41 individual sensor sites and 15 radio relay sites maintained by the Hanford Seismic Monitoring staff.

For the Hanford Seismic Network, there were 271 triggers during the second quarter of fiscal year 2003. Of these triggers, 141 were earthquakes.

Twenty earthquakes were located in the Hanford Seismic Network area. Stratigraphically 9 earthquakes occurred in the Columbia River basalt, 2 were earthquakes in the pre-basalt sediments, and 9 were earthquakes in the crystalline basement. Geographically, 6 earthquakes occurred in swarm areas, 2 earthquakes were associated with a major geologic structure, and 12 were classified as random events. 


\title{
Acronyms
}

\author{
BWIP Basalt Waste Isolation Project \\ CDPD Cellular Digital Packet Data \\ CRBG Columbia River Basalt Group \\ DOE U.S. Department of Energy \\ ETNA strong motion accelerometer manufactured by Kinemetrics \\ EWRN Eastern Washington Regional Network \\ FY fiscal year \\ GPS Global Positioning System \\ HSN Hanford Seismic Network \\ $\mathrm{M}_{\mathrm{c}} \quad$ Coda Length Magnitude \\ $\mathrm{M}_{\mathrm{L}} \quad$ Local Magnitude \\ $\mathrm{M}_{\mathrm{w}} \quad$ Moment Magnitude \\ PNNL Pacific Northwest National Laboratory \\ RAW Rattlesnake Mountain-Wallula Alignment \\ SMA strong motion accelerometer \\ USGS United States Geological Survey \\ UTC Universal Time, Coordinated \\ UW University of Washington \\ WHC Westinghouse Hanford Company
}




\section{Contents}

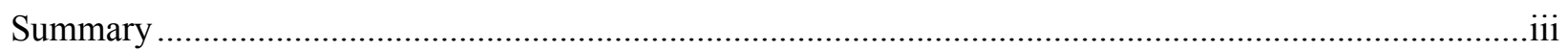

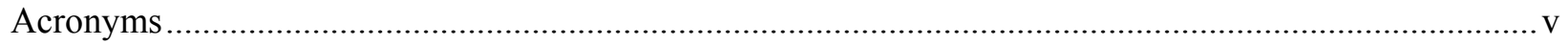

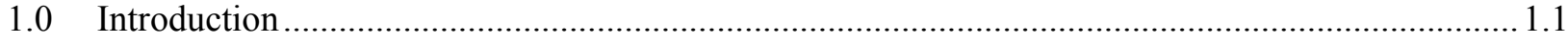

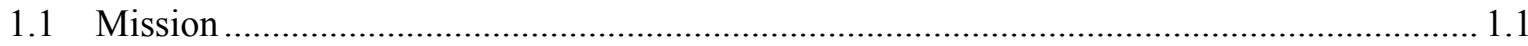

1.2 History of Seismic Monitoring at Hanford........................................................................ 1.1

1.3 Documentation and Reports ……………………………............................................... 1.2

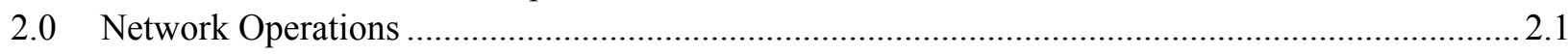

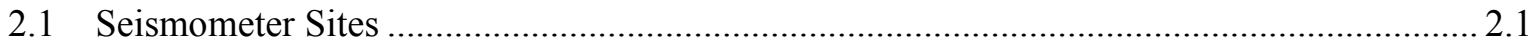

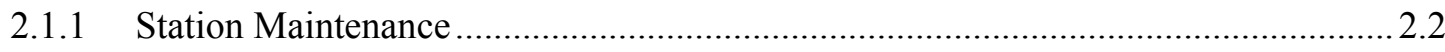

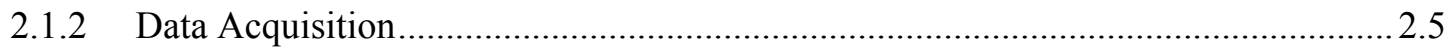

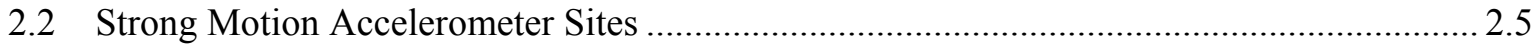

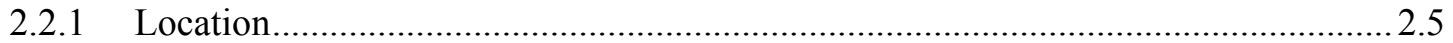

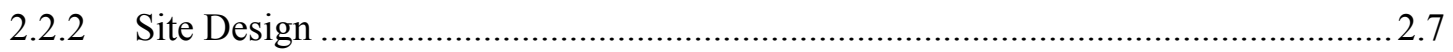

2.2.3 Strong Motion Accelerometer Operations Center ..................................................2. 2.8

2.2.4 Strong Motion Operational Characteristics ……………………………………....... 2.8

3.0 Earthquake Catalog Description............................................................................................ 3.1

3.1 Coda Length Magnitude ............................................................................................... 3.1

3.2 Velocity Model........................................................................................................... 3.1

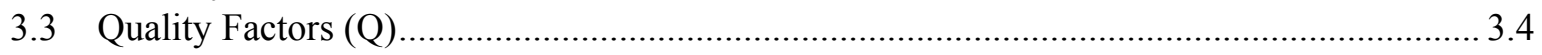

$4.0 \quad$ Geology and Tectonic Analysis ......................................................................................... 4.1

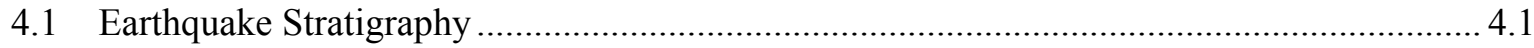

4.2 Geologic Structure Beneath the Monitored Area .................................................................. 4.1

4.3 Tectonic Pattern......................................................................................................... 4.4

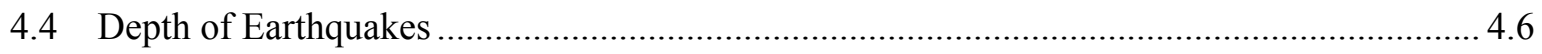

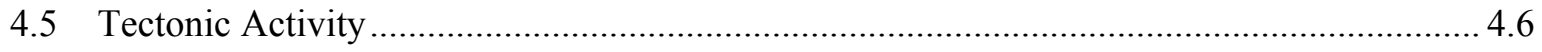

4.5.1 Second Quarter Summary .................................................................................... 4.6

4.5.2 Second Quarter Earthquakes of FY 2003 ………………………………….... 4.8

5.0 Strong Motion Accelerometer Operations ………………………………………………...... 5.1

5.1 Second Quarter of FY 2003 Triggers of the Hanford SMA Network ……………................ 5.1

6.0 Capabilities in the Event of a Significant Earthquake.................................................................... 6.1

6.1 Use of the SMA Network in the Event of an Earthquake ………........................................ 6.1

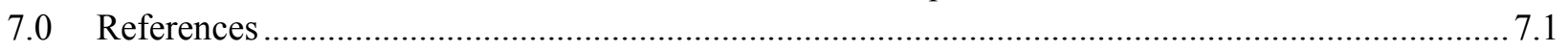




\section{Figures}

2.1 Locations of Seismograph Stations and Strong Motion Accelerometer Sites in the Hanford Seismic Network.

2.2 Locations of Seismograph Stations in the Eastern Washington Regional Network ........................ 2.4

2.3 Schematic Diagram of a Strong Motion Accelerometer Installation .............................................. 2.8

4.1 Tectonic Map of Columbia Basin Showing Major Seismic Source Structures ............................... 4.2

4.2 Geologic Cross Sections Through the Columbia Basin................................................................ 4.3

4.3 Locations of Known Earthquake Swarm Areas in the Hanford Monitoring Network Area ............. 4.5

4.4 All Earthquakes Recorded in the Hanford Monitoring Area Between January 1, 2003 and March 31, 2003

\section{Tables}

2.1 Seismic Stations in the Hanford Seismic Network 2.1

2.2 Seismic Stations in the Eastern Washington Regional Network......................................................... 2.3

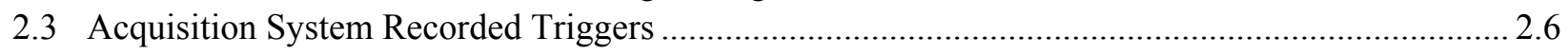

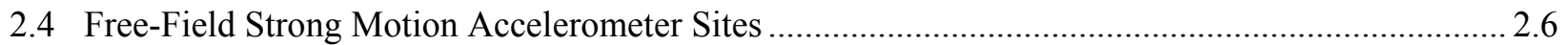

2.5 Instrument Parameters for the Kinemetrics ETNA ${ }^{\text {TM }}$ System in the Hanford SMA Network .......... 2.7

3.1 Seismic Velocities for Columbia Basin Stratigraphy ............................................................... 3.1

3.2 Local Seismic Data, October 1, 2002 to March 31, 2003 ............................................................ 3.2

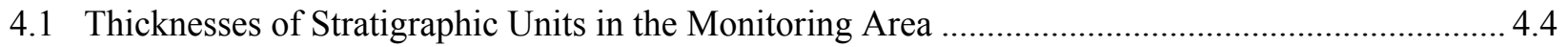

4.2 Number of Local Earthquakes Occurring in Stratigraphic Units................................................... 4.6

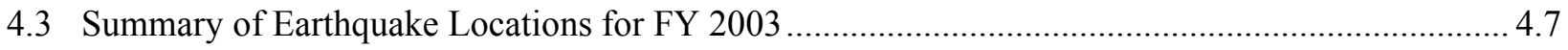




\subsection{Introduction}

This report covers seismic activity on and near the Hanford Site for the second quarter of fiscal year (FY) 2003. The report includes earthquake activity that occurred between January 1, 2003 and March 31, 2003 and the geologic interpretation of the sources of the earthquakes.

\subsection{Mission}

The principal mission of Hanford Seismic Monitoring at the Hanford Site is to insure compliance with DOE Order 420.1, "Facility Safety" and DOE Order G 420.1-1, Section 4.7, "Emergency Preparedness and Emergency Communications." DOE Order 420.1 establishes facility safety requirements related to nuclear safety design, criticality safety, fire protection, and natural phenomena hazards mitigation. For seismic monitoring, this order states:

\subsubsection{Natural Phenomena Detection.}

Facilities or sites with hazardous materials shall have instrumentation or other means to detect and record the occurrence and severity of seismic events.

The Seismic Monitoring Project supports Hanford Site emergency services organizations in complying with DOE Order G 420.1-1, Section 4.7, "Emergency Preparedness and Emergency Communications," by providing assistance in the event of an earthquake on the Hanford Site.

In addition, seismic monitoring provides an uninterrupted collection of high-quality raw seismic data from the Hanford Seismic Network (HSN) located on and around the Hanford Site, and the Eastern Washington Regional Network (EWRN). This report provides interpretations of seismic events from the Hanford Site and vicinity. Hanford Seismic Monitoring locates and identifies sources of seismic activity, monitors changes in the historical pattern of seismic activity at the Hanford Site, and builds a "local" earthquake database (processed data) that is permanently archived. The focus of this report is the precise location of earthquakes proximal to or on the Hanford Site, specifically between 46 degrees and 47 degrees north latitude and between 119 degrees and 120 degrees west longitude. Data from the EWRN and other seismic networks in the northwest provide the Seismic Monitoring Project with necessary regional input for the seismic hazards analysis at the Hanford Site. These seismic data are used to support Hanford Site contractors for waste management activities, Natural Phenomena Hazards assessments, and engineering design and construction.

\subsection{History of Seismic Monitoring at Hanford}

Seismic monitoring at the Hanford Site was established in 1969 by the United States Geological Survey (USGS) under a contract with the U.S. Atomic Energy Commission. In 1975, the University of Washington (UW) assumed responsibility for the network and subsequently expanded it. In 1979, the Basalt Waste Isolation Project (BWIP) became responsible for collecting seismic data for the Hanford Site as part of site characterization activities. Rockwell Hanford Operations, followed by Westinghouse Hanford 
Company (WHC), operated the local network and were the contract technical advisors for the EWRN operated and maintained by UW. Funding ended for BWIP in December 1988. Seismic monitoring and responsibility for the UW contract were then transferred to WHC's Environmental Division. Maintenance responsibilities for the EWRN also were assigned to WHC who made major upgrades to EWRN sites.

Effective October 1, 1996, seismic monitoring was transferred to the Pacific Northwest National Laboratory (PNNL). ${ }^{\text {(a) }}$ Seismic monitoring is part of PNNL's Applied Geology and Geochemistry Group, Environmental Technology Division.

The Hanford Strong Motion Accelerometer (SMA) network was constructed during 1997 and came on line in May 1997. It operated continuously until September 30, 1997 when it was mothballed due to lack of funding. Funding was restored on October 1, 1998 by joint agreement between the U.S. Department of Energy (DOE) and PNNL. Operation of the free-field sites resumed on November 20, 1999 and has operated continuously since that time.

\subsection{Documentation and Reports}

The Seismic Monitoring Project issues quarterly reports of local activity, an annual catalog of earthquake activity on and near the Hanford Site, and special-interest bulletins on local seismic events. The annual catalog includes the fourth quarter report for the fiscal year. Hanford Seismic Monitoring also provides information and special reports to other functions as requested. Earthquake information provided in these reports is subject to revisions if new data become available. In addition, an archive of all seismic data from the HSN is maintained by PNNL.

(a) Pacific Northwest National Laboratory is operated by Battelle Memorial Institute for the U.S. Department of Energy. 


\subsection{Network Operations}

\subsection{Seismometer Sites}

The seismic monitoring network consists of two designs of equipment and sites: seismometer sites and strong motion accelerometer (SMA) sites. Seismometer sites are designed to locate earthquakes and determine their magnitude and hypocenter location. SMA sites are designed to measure ground motion.

The HSN and the EWRN consist of 41 sensor sites. Most sites are in remote locations and require solar panels and batteries for power. The HSN uses 22 sites (Table 2.1 and Figure 2.1) and the EWRN uses

Table 2.1. Seismic Stations in the Hanford Seismic Network

The first column is the three-letter seismic station designator. The latitude and longitude, elevation above sea level in meters, and the full station name follow this. The locations of the stations are all in Washington; locations were derived from a Global Positioning System (GPS).

\begin{tabular}{|c|c|c|c|c|}
\hline Station & $\begin{array}{c}\text { Latitude } \\
\text { Deg. Min. N }\end{array}$ & $\begin{array}{c}\text { Longitude } \\
\text { Deg. Min. W }\end{array}$ & Elevation (m) & Station Name \\
\hline BEN & $46 \mathrm{~N} 31.13$ & 119W43.02 & 340 & Benson Ranch \\
\hline BRV & $46 \mathrm{~N} 49.12$ & 119W59.47 & 920 & Black Rock Valley \\
\hline BVW & $46 \mathrm{~N} 48.66$ & 119W52.99 & 670 & Beverly \\
\hline $\mathrm{CRF}$ & $46 \mathrm{~N} 49.50$ & 119W23.22 & 189 & Corfu \\
\hline ET3 & $46 \mathrm{~N} 34.64$ & $118 W 56.25$ & 286 & Eltopia Three \\
\hline$* \mathrm{FHE}$ & $46 \mathrm{~N} 57.11$ & 119W29.82 & 455 & Frenchman Hills East \\
\hline$* \mathrm{GBB}$ & $46 \mathrm{~N} 36.49$ & 119W37.62 & 177 & Gable Butte \\
\hline GBL & $46 \mathrm{~N} 35.92$ & 119W27.58 & 330 & Gable Mountain \\
\hline $\mathrm{H} 2 \mathrm{O}$ & $46 \mathrm{~N} 23.75$ & 119W25.38 & 158 & Water \\
\hline $\mathrm{LOC}$ & $46 \mathrm{~N} 43.02$ & $119 \mathrm{~W} 25.85$ & 210 & Locke Island \\
\hline MDW & $46 \mathrm{~N} 36.79$ & $119 W 45.66$ & 330 & Midway \\
\hline $\mathrm{MJ} 2$ & $46 \mathrm{~N} 33.45$ & 119W21.54 & 146 & May Junction Two \\
\hline OT3 & $46 \mathrm{~N} 40.14$ & 119W13.98 & 322 & Othello Three \\
\hline PRO & $46 \mathrm{~N} 12.73$ & 119W41.15 & 550 & Prosser \\
\hline RED & $46 \mathrm{~N} 17.92$ & 119W26.30 & 366 & Red Mountain \\
\hline RSW & $46 \mathrm{~N} 23.67$ & 119W35.48 & 1,045 & Rattlesnake Mountain \\
\hline SNI & $46 \mathrm{~N} 27.85$ & 119W39.60 & 312 & Snively Ranch \\
\hline VT2 & $46 N 58.04$ & 119W58.95 & 1,270 & Vantage 2 \\
\hline WA2 & $46 \mathrm{~N} 45.32$ & 119W33.94 & 244 & Wahluke Slope \\
\hline WIW & $46 \mathrm{~N} 25.76$ & $119 \mathrm{~W} 17.26$ & 128 & Wooded Island \\
\hline WRD & $46 \mathrm{~N} 58.20$ & 119W08.69 & 375 & Warden \\
\hline YPT & $46 \mathrm{~N} 02.93$ & $118 W 57.73$ & 325 & Yellepit \\
\hline
\end{tabular}




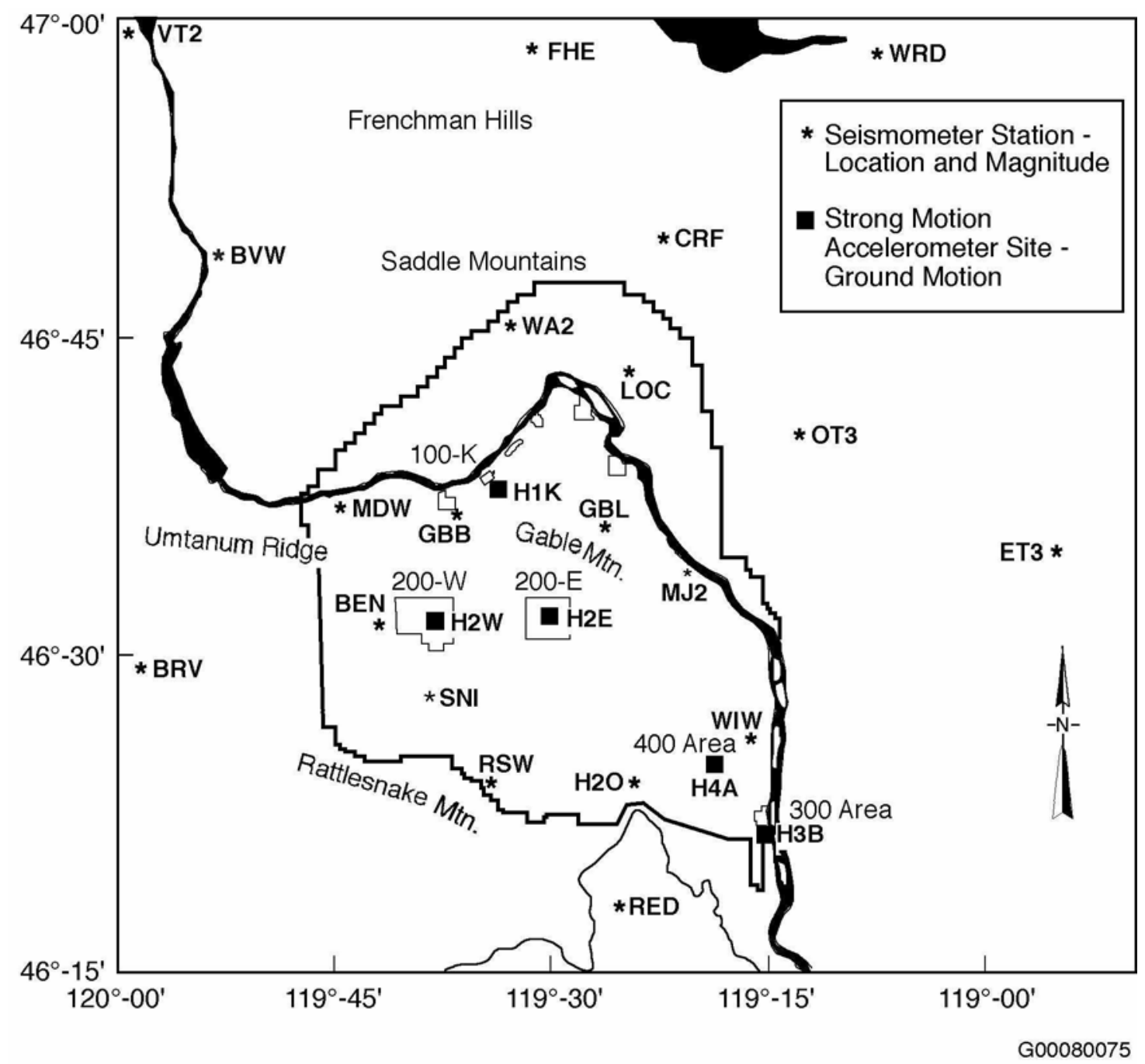

Figure 2.1. Locations of Seismograph Stations and Strong Motion Accelerometer Sites in the Hanford Seismic Network (see Table 2.1 for description of locations). Locations for Prosser (PRO) and Yellepit (YPT) are not shown. See Figure 2.2 for the locations of those sites.

35 sites (Table 2.2 and Figure 2.2); both networks share 16 sites. The networks have 45 combined data channels because Gable Butte and Frenchman Hills East are three-component sites, each consisting of one vertical, one north-south horizontal, and one east-west horizontal data channel. Both networks use 15 additional telemetry relay sites. Data from all sites or relays are transmitted to the Sigma V building, Richland, Washington.

\subsubsection{Station Maintenance}

The HSN's maintenance records for the seismic sensor and relay sites are on file in the Hanford Seismic Monitoring office, Sigma V Building, Richland Washington. 
Table 2.2. Seismic Stations in the Eastern Washington Regional Network

\begin{tabular}{|c|c|c|c|c|}
\hline Station & $\begin{array}{c}\text { Latitude } \\
\text { Deg. Min. N. }\end{array}$ & $\begin{array}{c}\text { Longitude } \\
\text { Deg. Min. W. }\end{array}$ & Elevation (m) & Station Name \\
\hline BRV & $46 \mathrm{~N} 29.12$ & 119W59.47 & 920 & Black Rock Valley \\
\hline BVW & $46 \mathrm{~N} 48.66$ & 119W52.99 & 670 & Beverly \\
\hline CBS & $47 \mathrm{~N} 48.26$ & $120 \mathrm{~W} 02.50$ & 1,067 & Chelan Butte, South \\
\hline CRF & $46 \mathrm{~N} 49.50$ & $119 \mathrm{~W} 23.22$ & 189 & Corfu \\
\hline DPW & $47 \mathrm{~N} 52.25$ & $118 \mathrm{~W} 12.17$ & 892 & Davenport \\
\hline DY2 & $47 N 59.11$ & $119 \mathrm{~W} 46.28$ & 890 & Dyer Hill Two \\
\hline ELL & $46 \mathrm{~N} 54.58$ & 120W33.98 & 789 & Ellensburg \\
\hline $\mathrm{EPH}$ & $47 \mathrm{~N} 21.38$ & $119 \mathrm{~W} 35.76$ & 661 & Ephrata \\
\hline ET3 & $46 \mathrm{~N} 34.64$ & $118 \mathrm{~W} 56.25$ & 286 & Eltopia Three \\
\hline ETW & $47 \mathrm{~N} 36.26$ & 120W19.94 & 1,477 & Entiat \\
\hline$*$ FHE & 46N57.11 & $119 \mathrm{~W} 29.82$ & 455 & Frenchman Hills East \\
\hline$*$ GBL & $46 \mathrm{~N} 35.92$ & 119W27.58 & 330 & Gable Mountain \\
\hline LNO & $45 \mathrm{~N} 52.31$ & $118 \mathrm{~W} 17.11$ & 771 & Lincton Mountain, Oregon \\
\hline LOC & $46 \mathrm{~N} 43.02$ & $119 \mathrm{~W} 25.85$ & 210 & Locke Island \\
\hline MDW & $46 \mathrm{~N} 36.79$ & $119 \mathrm{~W} 45.66$ & 330 & Midway \\
\hline MJ2 & $46 \mathrm{~N} 33.45$ & 119W21.54 & 146 & May Junction Two \\
\hline MOX & $46 \mathrm{~N} 34.64$ & $120 \mathrm{~W} 17.89$ & 501 & Moxee City \\
\hline NAC & $46 \mathrm{~N} 43.99$ & 120W49.42 & 728 & Naches \\
\hline NEL & $48 \mathrm{~N} 04.21$ & 120W20.41 & 1,500 & Nelson Butte \\
\hline OD2 & $47 \mathrm{~N} 23.26$ & $118 \mathrm{~W} 42.58$ & 553 & Odessa Two \\
\hline OT3 & $46 \mathrm{~N} 40.14$ & $119 \mathrm{~W} 13.98$ & 322 & Othello Three \\
\hline PAT & $45 \mathrm{~N} 52.92$ & 119W45.14 & 262 & Paterson \\
\hline PRO & $46 \mathrm{~N} 12.73$ & $119 \mathrm{~W} 41.15$ & 550 & Prosser \\
\hline RSW & $46 \mathrm{~N} 23.67$ & 119W35.48 & 1,045 & Rattlesnake Mountain \\
\hline SAW & $47 \mathrm{~N} 42.10$ & $119 \mathrm{~W} 24.03$ & 701 & St. Andrews \\
\hline TBM & $47 \mathrm{~N} 10.20$ & 120W35.88 & 1,006 & Table Mountain \\
\hline TRW & $46 \mathrm{~N} 17.32$ & $120 \mathrm{~W} 32.31$ & 723 & Toppenish Ridge \\
\hline TWW & $47 \mathrm{~N} 08.29$ & 120W52.10 & 1,027 & Teanaway \\
\hline VT2 & 46N58.04 & $119 \mathrm{~W} 58.95$ & 1,270 & Vantage Two \\
\hline WA2 & $46 \mathrm{~N} 45.32$ & $119 \mathrm{~W} 33.94$ & 244 & Wahluke Slope Two \\
\hline WAT & $47 \mathrm{~N} 41.92$ & 119 W57.24 & 821 & Waterville \\
\hline WIW & $46 \mathrm{~N} 25.76$ & $119 \mathrm{~W} 17.26$ & 128 & Wooded Island \\
\hline WRD & $46 \mathrm{~N} 58.20$ & 119W08.69 & 375 & Warden \\
\hline YA2 & $46 \mathrm{~N} 31.60$ & $120 \mathrm{~W} 31.80$ & 652 & Yakima Two \\
\hline YPT & $46 \mathrm{~N} 02.93$ & $118 \mathrm{~W} 57.73$ & 325 & Yellepit \\
\hline
\end{tabular}




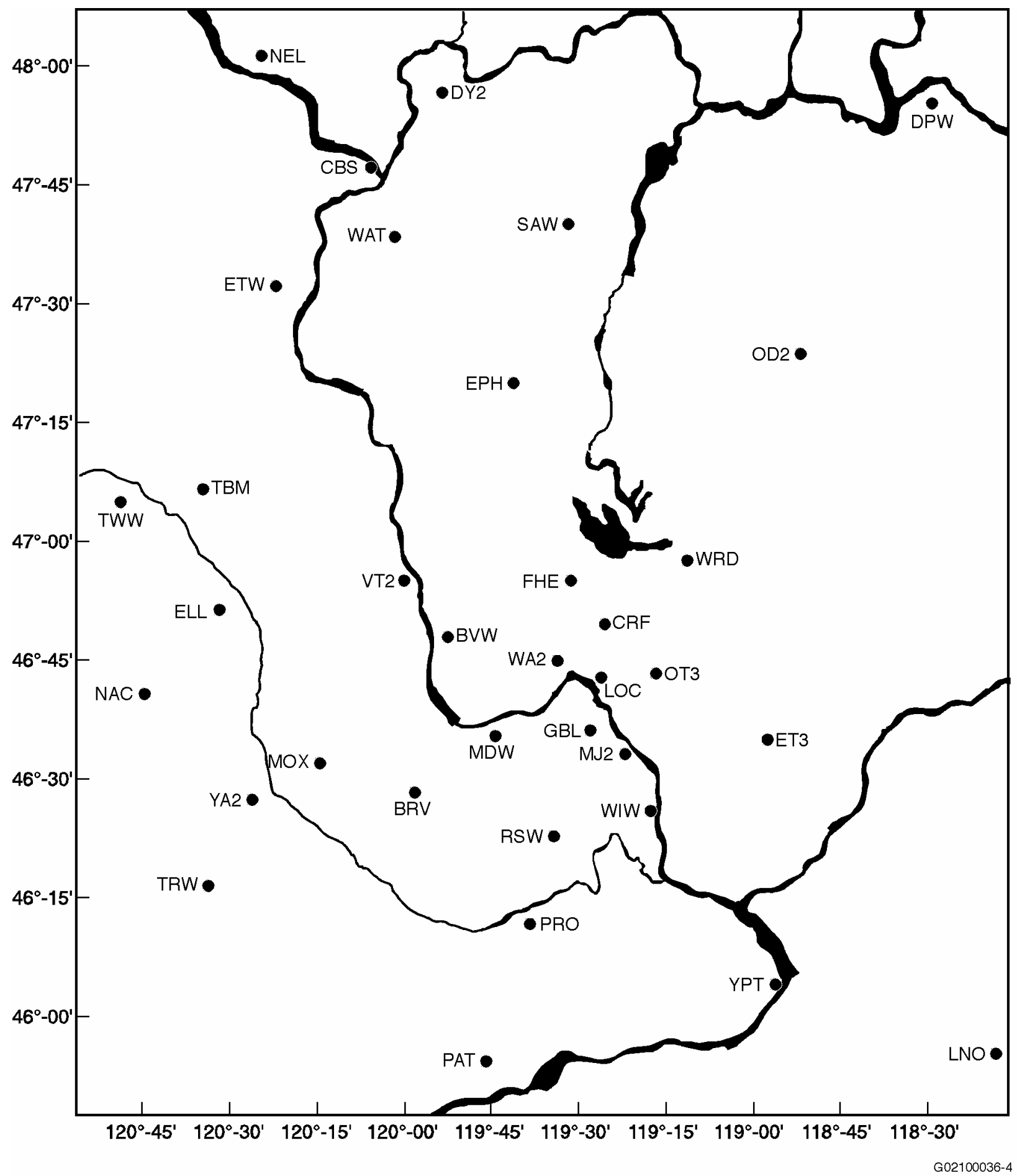

Figure 2.2. Locations of Seismograph Stations in the Eastern Washington Regional Network (see Table 2.2 for location descriptions). 


\subsubsection{Data Acquisition}

The signals from the seismometer sites are monitored for changes in signal amplitude that are expected from earthquakes. The seismic network is subdivided into spatial groupings of stations that are monitored for nearly simultaneous amplitude changes, resulting in triggering a permanent recording of the events. The groupings and associated weighting schemes are designed to allow very small seismic events to be recorded and to minimize false triggers. Events are classified as local (south-central Washington near the Hanford Site), regional (Western U.S. and Canada), and teleseisms (from farther distances around the world). Local and regional events are usually earthquakes, but quarry and mining explosions are also recorded. Quarry and mining explosions can usually be identified from wave characteristics, time of day, and through confirmation with local government agencies and industries. Frequently, military exercises at the U.S. Army's Yakima Training Center produce a series of acoustic shocks that unavoidably trigger the recording system. Sonic booms and thunder also produce acoustic signals that trigger the recording system.

A PC-based system (Earthworm system) adapted from a USGS program and the UW system was implemented at Hanford during FY 1999. One system has been in continuous operation since January 6 , 1999. A second, backup PC system was installed in mid-March 1999, and both systems have been running in parallel since that time. The hardware and software have been periodically upgraded. Data from triggers are collected on a SUN ${ }^{\text {TM }}$ (registered trademark of Sun Microsystems, Santa Clara, California) workstation that is used to determine earthquake locations and magnitudes (Section 3). Although the two systems are practically identical, there is enough granularity (signal-to-noise) in the trigger timing that they sometimes record exclusive events. In nearly all cases, these exclusive triggers are "false" triggers, not earthquakes or quarry blasts (i.e., from acoustic sources). The remainders are from barely detectable, small signals from regional and teleseismic earthquakes.

The types and numbers of triggers recorded in FY 2003 by the seismic acquisition system are summarized in Table 2.3.

\subsection{Strong Motion Accelerometer Sites}

\subsubsection{Location}

The Hanford SMA network consists of five free-field SMA sites (see Figure 2.1) (Table 2.4). There is one free-field SMA located in each of the 200-East and 200-West Areas, 200 Separations Areas, one adjacent to the K Basins in the 100-K Area, one adjacent to the 400 Area where the Fast Flux Test Reactor is located, and one at the south end of the 300 Area. With the termination of the Fast Flux Test Reactor and draining of the liquid sodium coolant taking place now, we are making plans to terminate this site and move the instrument to a new location.

The instrumentation locations were chosen based on two criteria (Moore and Reidel 1996): 1) instruments should be located in areas having the highest densities of people and 2) instruments should be located in areas having hazardous facilities. Some of the highest concentrations of employees at Hanford are in the 200 East and West Areas, 100-K Area, the Fast Flux Test Facility (400 Area), and the 300 Area. The 200 Areas are where high-level radioactive waste from past processing of fuel rods is stored in 
Table 2.3. Acquisition System Recorded Triggers

\begin{tabular}{|c|c|c|c|c|c|c|}
\hline Event Type & $\begin{array}{c}\text { First } \\
\text { Quarter } \\
\end{array}$ & $\begin{array}{l}\text { Second } \\
\text { Quarter } \\
\end{array}$ & $\begin{array}{c}\text { Third } \\
\text { Quarter }\end{array}$ & $\begin{array}{l}\text { Fourth } \\
\text { Quarter }\end{array}$ & Total & Description \\
\hline $\begin{array}{l}\text { South-Central } \\
\text { Washington }\end{array}$ & 46 & 40 & - & - & 86 & $\begin{array}{l}\text { Seismic events in south-central } \\
\text { Washington and north-central Oregon } \\
\text { that triggered the HSN. }\end{array}$ \\
\hline Regional & 44 & 47 & - & - & 91 & $\begin{array}{l}\text { Seismic events in the Western United } \\
\text { States and Canada. }\end{array}$ \\
\hline Teleseism & 81 & 54 & - & - & 135 & $\begin{array}{l}\text { Seismic events at farther distances from } \\
\text { around the world. }\end{array}$ \\
\hline $\begin{array}{l}\text { Total Earthquake } \\
\text { Events }\end{array}$ & 171 & 141 & - & - & 312 & Total number of earthquake triggers. \\
\hline $\begin{array}{l}\text { Total Triggers on } \\
\text { Primary System }\end{array}$ & 342 & 271 & - & - & 613 & $\begin{array}{l}\text { Total number of triggers examined. } \\
\text { Includes all sources of triggers. }\end{array}$ \\
\hline Local Explosions & 2 & 5 & - & - & 7 & $\begin{array}{l}\text { Quarry blasts, typically, within the } 46-47 \\
\text { degrees north latitude and 119-120 } \\
\text { degrees west longitude. }\end{array}$ \\
\hline Local Earthquakes & 29 & 20 & - & - & 49 & $\begin{array}{l}\text { Seismic events within the } 46-47 \text { degrees } \\
\text { north latitude and 119-120 degrees west } \\
\text { longitude. }\end{array}$ \\
\hline
\end{tabular}

Table 2.4. Free-Field Strong Motion Accelerometer Sites

\begin{tabular}{|c|c|c|c|}
\hline Site & Site ID & Location & $\begin{array}{c}\text { Latitude } \\
\text { Longitude } \\
\text { Elevation } \\
\end{array}$ \\
\hline $100-$ K Area & $\mathrm{H} 1 \mathrm{~K}$ & South of K Basins outside 100 Area fence lines. & $\begin{array}{c}46^{\circ} 38.51^{\prime} \\
119^{\circ} 35.53 \\
152 \mathrm{~m}\end{array}$ \\
\hline 200 East Area & $\mathrm{H} 2 \mathrm{E}$ & $\begin{array}{l}\text { East of B Plant; north of } 7^{\text {th }} \text { Street and east of Baltimore } \\
\text { Avenue. }\end{array}$ & $\begin{array}{c}46^{\circ} 33.58^{\prime} \\
119^{\circ} 32.00^{\prime} \\
210 \mathrm{~m}\end{array}$ \\
\hline 200 West Area & $\mathrm{H} 2 \mathrm{~W}$ & $\begin{array}{l}\text { Northeast of Plutonium Finishing Plant (PFP); north of } \\
19^{\text {th }} \text { street and east of Camden Avenue. }\end{array}$ & $\begin{array}{c}46^{\circ} 33.23^{\prime} \\
119^{\circ} 37.51^{\prime} \\
206 \mathrm{~m}\end{array}$ \\
\hline 300 Area & $\mathrm{H} 3 \mathrm{~A}$ & $\begin{array}{l}\text { South end of } 300 \text { Area inside fence lines. (NE 1/4, SW } \\
1 / 4 \text {, Sec. } 11, \mathrm{~T} 10 \mathrm{~N}, \mathrm{R} 28 \mathrm{E}) \text {. }\end{array}$ & $\begin{array}{c}46^{\circ} 21.83^{\prime} \\
119^{\circ} 16.55^{\prime} \\
119 \mathrm{~m}\end{array}$ \\
\hline 400 Area & $\mathrm{H} 4 \mathrm{~A}$ & $\begin{array}{l}500 \text { feet from fence line on east side of facility and } \\
\text { north of parking area). }\end{array}$ & $\begin{array}{c}46^{\circ} 26.13^{\prime} \\
119^{\circ} 21.30^{\prime} \\
171 \mathrm{~m}\end{array}$ \\
\hline
\end{tabular}

single-shell and double-shell tanks. In addition, the Canister Storage Facility that holds encapsulated spent fuel rods is in 200 East Area. The 100-K Area contains the K Basins where spent fuel rods from the $\mathrm{N}$ Reactor are stored prior to encapsulation. The Cold Vacuum Drying Facility, located in the 100-K Area, is used to encapsulate spent fuel rods from the K Basins prior to shipment to the Canister Storage Building in 200 East Area. 


\subsubsection{Site Design}

All free-field SMA sites consist of a four-panel solar array and two 30-gallon galvanized drums. Each panel has a maximum 42 watt output. The two 30-gallon drums are set in the ground such that the base of the drum is about $1 \mathrm{~m}$ below the surface. One drum houses only the SMA; the other drum, which is connected via a sealed conduit to the SMA drum, contains the batteries. Communication is through a Cellular Digital Packet Data (CDPD) system, which provides a continuous radio data-link with the AT\&T internet service. This CDPD system along with the solar regulator is housed in a small enclosure mounted at the rear of the solar array. The enclosure serves as a junction box for all cabling between in the drums and outside the drums through conduit. The antenna for the CDPD is mounted on top of the enclosure. The enclosure permits quick access to check battery conditions and a connection directly to the RS-232 port of the SMA without removing the drum lids. The CDPD system is scheduled to be terminated by AT\&T and replaced with a new system in January 2004.

The SMA instruments are three-component units consisting of one vertical, one north-south horizontal, and one east-west horizontal data channel. The instruments in use are the ETNA ${ }^{\mathrm{TM}}$ system (registered trademark of Kinemetrics, Inc., Pasadena, California). Instrument specifications are summarized in Table 2.5. In addition to the three-component SMAs, each ETNA SMA unit contains a computer, Global Positioning System (GPS) receiver (Figure 2.3). These systems are housed in a watertight box.

The CDPD system provides the internet address connection to access the system. Stations can be monitored from any computer, and data can be downloaded to a dedicated computer in the seismic monitoring laboratory. The data can also be downloaded directly at each site via a built in cable connection at the enclosure in case of communication failure.

Table 2.5. Instrument Parameters for the Kinemetrics ETNA ${ }^{\text {TM }}$ System in the Hanford SMA Network

\begin{tabular}{||l|l||}
\hline \multicolumn{1}{||c||}{ Parameter } & \multicolumn{1}{c||}{ Value or Range } \\
\hline \hline Sensor & Tri-axial Force Balance Accelerometer orthogonally oriented with internal standard \\
\hline Type & $\pm 2 \mathrm{~g}^{(\mathrm{a})}$ \\
\hline Full-Scale & 0 -50 Hz \\
\hline Frequency Range & Approximately $70 \%$ critical $^{(\mathrm{a})}$ \\
\hline Damping & 3 \\
\hline Data Acquisition & 18 -bit resolution @ 200 samples/second \\
\hline Number of Channels & Real-time, RS-232 Output Stream \\
\hline Sample Rate & $0.1-12.5 \mathrm{~Hz}$ \\
\hline Digital Output & $0.10 \%-0.20 \% \mathrm{~g}$ (b) \\
\hline Seismic Trigger & Not activated \\
\hline Filter & $10 \mathrm{sec}$ \\
\hline Trigger level & $40 \mathrm{sec}$ \\
\hline Alarm (call-out) Threshold \\
\hline Pre-event Memory & Post-event Time \\
\hline $\begin{array}{l}\text { (a) Setting is dependent on instrument calibration. } \\
\text { (b) See Section 2.2.4 for discussion of trigger thresholds. }\end{array}$ \\
\hline
\end{tabular}




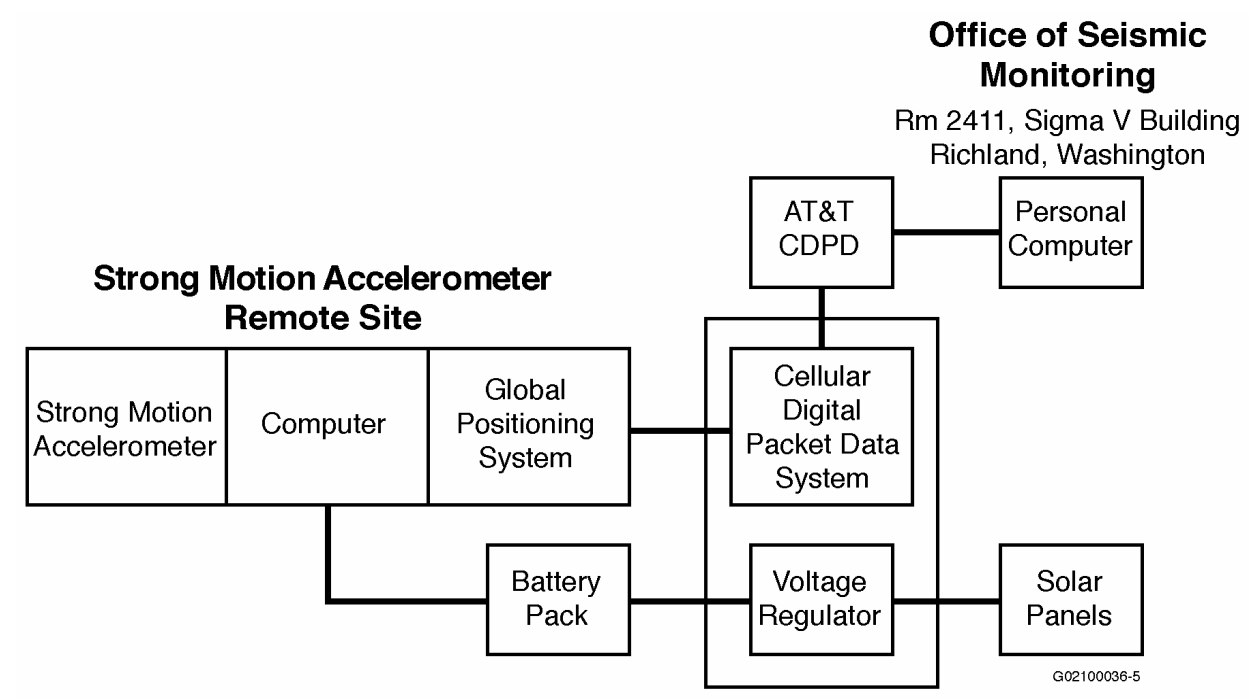

Figure 2.3. Schematic Diagram of a Strong Motion Accelerometer Installation

The SMAs have an internal GPS receiver used principally to link it to the National Bureau of Standards timing system. The GPS antenna is mounted on the enclosure at the rear of the solar array. The GPS is internally activated approximately every 4 hours and checks the "location of the instrument" and the time. Any differences between the internal clock and the GPS time are recorded and saved by the SMA. Any corrections to the internal timing are made automatically. Typically, the greatest correction recorded is approximately 4 milliseconds.

\subsubsection{Strong Motion Accelerometer Operations Center}

The combined operations, data recording, data interpretation, and maintenance facility is located in the Sigma V building and is operated by the PNNL Seismic Monitoring Team.

\subsubsection{Strong Motion Operational Characteristics}

The signals from the three-accelerometer channels at each site are digitized with a 24-bit digitizer and temporarily stored in a memory buffer. The sampling rate of the digitizer is set to $200 \mathrm{samples} / \mathrm{second}$. The three channels are monitored for signals that equal or exceed a programmable trigger threshold. When one accelerometer channel is triggered, the other channels automatically record. The nominal threshold used is $0.05 \%$ of the full-scale range of $2.0 \mathrm{~g}$ ( $\mathrm{g}$ is the acceleration of gravity, $9.8 \mathrm{~m} / \mathrm{s}^{2}$ or $32 \mathrm{ft} / \mathrm{s}^{2}$ ) or $0.001 \mathrm{~g}$. Threshold trigger levels are being adjusted to trigger infrequently on the noise sources (e.g., vehicles, sonic booms) near each site. This will provide ground motion data for smaller, non-damaging earthquakes that can be useful in estimating the ground motion expected from larger earthquakes, and to confirm correct operation of the instruments by analyzing the smaller-amplitude triggers. The recorders store information for 10 seconds before the trigger threshold is exceeded and for 40 seconds after the trigger ceases to be exceeded. 


\subsection{Earthquake Catalog Description}

Seismic Monitoring staff uses an interactive program XPED developed at the University of Washington to determine earthquake locations and magnitudes. This program operates on the sections of time saved in files by the trigger algorithm of the Earthworm system. It provides the user with the ability to measure the arrival times and durations of seismic waves from earthquakes and determine the locations and magnitudes of the events. Locations of teleseismic and regional earthquakes are interpreted and saved for operational and quality review and documentation, and are not reported here. Local earthquakes near the Hanford Site $\left(46^{\circ}-47^{\circ} \mathrm{N}, 119^{\circ}-120^{\circ} \mathrm{W}\right)$ are reported in this report (Table 3.2). Other earthquakes in southeast Washington are kept on file.

\subsection{Coda Length Magnitude}

Coda-length magnitude $\left(\mathrm{M}_{\mathrm{c}}\right)$, an estimate of local magnitude $\left(\mathrm{M}_{\mathrm{L}}\right)$ (Richter 1958), is calculated using the coda-length/magnitude relationship determined for Washington State by Crosson (1972).

This relationship is:

$$
\mathrm{M}_{\mathrm{c}}=2.82 \log (\mathrm{D})-2.46
$$

where $\mathrm{D}$ is the duration of the observed signal.

\subsection{Velocity Model}

The program XPED uses the velocities and layer depths given in Table 3.1. This model does not include a surficial layer for sediments of the Hanford and Ringold Formations on the Hanford or Ringold sediments because most stations are located on basalt. Time corrections, which account for elevation, or local differences in the velocity model (i.e., stations on sedimentary layers), are determined empirically from sets of accurately-located earthquakes and explosions in the region.

Table 3.1. Seismic Velocities for Columbia Basin Stratigraphy (from Rohay et al. 1985)

\begin{tabular}{||c|l|c||}
\hline $\begin{array}{c}\text { Depth to Top of } \\
\text { Velocity Layer }(\mathbf{k m})\end{array}$ & \multicolumn{1}{|c|}{ Stratigraphy } & $\begin{array}{c}\text { Velocity } \\
\text { (km/sec) }\end{array}$ \\
\hline \hline 0.0 & Saddle Mountains and Wanapum Basalts and intercalated Ellensburg Formation & 3.7 \\
\hline 0.4 & Grande Ronde Basalt and pre-basalt sediments & 5.2 \\
\hline 8.5 & Crystalline Basement, Layer 1 & 6.1 \\
\hline 13.0 & Crystalline Basement, Layer 2 & 6.4 \\
\hline 23.0 & Sub-basement & 7.1 \\
\hline 38.0 & Mantle & 7.9 \\
\hline
\end{tabular}


Table 3.2. Local Seismic Data, October 1, 2002 to March 31, 2003

\begin{tabular}{|c|c|c|c|c|c|c|c|c|c|c|c|c|c|}
\hline Event ID & Type & Date & Time & Latitutde & Longitude & Depth & Mag & 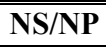 & Gap & Dmin & 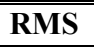 & $\overline{Q Q}$ & Location \\
\hline 01101700254 & & $01 / 10 / 17$ & $00: 26: 02.61$ & 46N21.97 & $119 \mathrm{~W} 37.05$ & 4.50 & 0.3 & $7 / 08$ & 138 & 3 & 0.29 & $\mathrm{BC}$ & $21.2 \mathrm{~km}$ NNE of Prosser \\
\hline $\mid 02100619012$ & & $02 / 10 / 06$ & $19: 01: 46.23$ & $46 \mathrm{~N} 06.92$ & $119 \mathrm{~W} 26.70$ & 9.16 & 0.7 & $12 / 15$ & 193 & 20 & 0.11 & $\mathrm{AD}$ & $22.1 \mathrm{~km}$ SSW of Richland \\
\hline 02100619322 & & $02 / 10 / 06$ & $19: 32: 42.27$ & $46 \mathrm{~N} 07.43$ & 119W26.63 & 7.55 & 0.6 & $7 / 11$ & 316 & 19 & 0.10 & $\mathrm{BD}$ & $21.3 \mathrm{~km} \mathrm{SSW}$ of Richland \\
\hline $\mid 02100803071$ & & $02 / 10 / 08$ & $03: 07: 41.10$ & $46 \mathrm{~N} 18.67$ & $119 \mathrm{~W} 32.30$ & 7.98 & 0.7 & $14 / 14$ & 124 & 7 & 0.09 & $\mathrm{AB}$ & $19.3 \mathrm{~km} \mathrm{~W}$ of Richland \\
\hline $\mid 02101205244$ & & $02 / 10 / 12$ & $05: 25: 06.45$ & $46 \mathrm{~N} 50.60$ & 119W44.22 & 3.49 & 1.5 & $20 / 21$ & 70 & 11 & 0.13 & $\mathrm{AC}$ & $22.7 \mathrm{~km}$ SE of Vantage \\
\hline $\mid 02102210321$ & & $02 / 10 / 22$ & $10: 32: 33.39$ & $46 \mathrm{~N} 50.71$ & $119 \mathrm{~W} 47.35$ & 2.42 & 2.7 & $39 / 40$ & 43 & 8 & 0.17 & BB & $19.4 \mathrm{~km} \mathrm{SE}$ of Vantage \\
\hline |02102806211 & & $02 / 10 / 28$ & 06:21:41.82 & $46 \mathrm{~N} 23.02$ & 119W35.24 & 18.17 & 0.4 & $14 / 14$ & 196 & 1 & 0.07 & $\mathrm{AD}$ & $18.5 \mathrm{~km} \mathrm{WSW}$ of 400 Area \\
\hline $\mid 02103013381$ & & $02 / 10 / 30$ & $13: 38: 36.14$ & $46 \mathrm{~N} 36.49$ & $119 \mathrm{~W} 46.90$ & 8.45 & 0.0 & $14 / 16$ & 111 & 1 & 0.09 & $\mathrm{AB}$ & $12.4 \mathrm{~km} \mathrm{WNW}$ of $200 \mathrm{West}$ \\
\hline $\mid 02103101295$ & & $02 / 10 / 31$ & $01: 30: 16.57$ & $46 \mathrm{~N} 50.28$ & 119W19.78 & 2.65 & 0.5 & $16 / 16$ & 90 & 4 & 0.07 & $\mathrm{AA}$ & $12.5 \mathrm{~km} \mathrm{~W}$ of Othello \\
\hline $\mid 02103120351$ & & $02 / 10 / 31$ & $20: 35: 41.98$ & $46 \mathrm{~N} 43.69$ & 119W31.04 & 0.02 & -0.1 & $9 / 10$ & 73 & 4 & 0.13 & AA & $11.4 \mathrm{~km} \mathrm{NNE}$ of $100-\mathrm{K}$ Area \\
\hline 02110323592 & & $02 / 11 / 03$ & $23: 59: 49.84$ & $46 \mathrm{~N} 47.34$ & 119W10.63 & 14.87 & 1.3 & $30 / 41$ & 113 & 14 & 0.13 & $\mathrm{AB}$ & $4.3 \mathrm{~km} \mathrm{~S}$ of Othello \\
\hline $\mid 02110403334$ & & $02 / 11 / 04$ & $03: 34: 02.26$ & $46 \mathrm{~N} 14.69$ & 119W01.00 & 12.69 & 0.3 & $12 / 17$ & 159 & 22 & 0.17 & $\mathrm{BC}$ & $6.3 \mathrm{~km} \mathrm{E}$ of Pasco \\
\hline $\mid 02110407344$ & & $02 / 11 / 04$ & $07: 35: 06.62$ & $46 \mathrm{~N} 27.32$ & 119W34.89 & 15.86 & -0.1 & $10 / 14$ & 92 & 6 & 0.05 & $\mathrm{AB}$ & $12.2 \mathrm{~km} \mathrm{SSW}$ of 200 East \\
\hline $\mid 02110413204$ & & $02 / 11 / 04$ & $13: 21: 08.05$ & $46 \mathrm{~N} 40.55$ & 119W34.98 & 13.20 & 0.4 & $13 / 16$ & 65 & 8 & 0.08 & $\mathrm{AA}$ & $3.9 \mathrm{~km} \mathrm{NNE}$ of $100-\mathrm{K}$ Area \\
\hline $\mid 02110504052$ & & $02 / 11 / 05$ & 04:05:53.58 & $46 \mathrm{~N} 27.17$ & 119W36.81 & 15.00 & 0.6 & $13 / 15$ & 111 & 3 & 0.06 & $\mathrm{AB}$ & $11.8 \mathrm{~km} \mathrm{~S}$ of $200 \mathrm{West}$ \\
\hline 02110612274 & & $02 / 11 / 06$ & $12: 28: 05.14$ & $46 \mathrm{~N} 33.04$ & 119W13.83 & 16.23 & 0.3 & $13 / 18$ & 150 & 9 & 0.08 & $\mathrm{AC}$ & $16.2 \mathrm{~km} \mathrm{NE}$ of 400 Area \\
\hline 02110800555 & & $02 / 11 / 08$ & $00: 56: 19.55$ & $46 \mathrm{~N} 40.73$ & $119 \mathrm{~W} 38.26$ & 15.84 & -0.2 & $16 / 20$ & 61 & 7 & 0.11 & AA & $5.1 \mathrm{~km} \mathrm{NW}$ of $100-\mathrm{K}$ Area \\
\hline $\mid 02110920575$ & & $02 / 11 / 09$ & 20:58:11.00 & $46 \mathrm{~N} 33.75$ & 119W35.26 & 24.08 & 0.3 & $14 / 18$ & 65 & 5 & 0.07 & AA & $3.9 \mathrm{~km} \mathrm{E}$ of $200 \mathrm{West}$ \\
\hline 02111001232 & & $02 / 11 / 10$ & $01: 23: 44.41$ & $46 \mathrm{~N} 50.06$ & $119 \mathrm{~W} 33.54$ & 14.68 & 0.2 & $11 / 14$ & 130 & 8 & 0.11 & $\mathrm{AB}$ & $21.6 \mathrm{~km} \mathrm{~N}$ of $100-\mathrm{K}$ Area \\
\hline 02111023574 & & $02 / 11 / 10$ & 23:58:05.92 & 46N51.91 & 119W25.36 & 18.98 & 0.4 & $14 / 16$ & 107 & 5 & 0.14 & $\mathrm{AB}$ & $20.0 \mathrm{~km} \mathrm{WNW}$ of Othello \\
\hline $\mid 02111609344$ & & $02 / 11 / 16$ & $09: 35: 06.62$ & $46 \mathrm{~N} 50.24$ & $119 \mathrm{~W} 33.07$ & 15.94 & 1.4 & $32 / 36$ & 31 & 9 & 0.13 & AA & $22.0 \mathrm{~km} \mathrm{~N}$ of $100-\mathrm{K}$ Area \\
\hline 02112004435 & & $02 / 11 / 20$ & $04: 44: 22.18$ & $46 \mathrm{~N} 36.66$ & 119W46.10 & 16.08 & 0.1 & $6 / 11$ & 269 & 0 & 0.06 & $\mathrm{AD}$ & $11.6 \mathrm{~km} \mathrm{WNW}$ of $200 \mathrm{West}$ \\
\hline |02112004482 & & $02 / 11 / 20$ & $04: 48: 43.71$ & $46 \mathrm{~N} 36.91$ & 119W46.32 & 17.06 & 0.0 & $7 / 10$ & 180 & 0 & 0.06 & $\mathrm{AC}$ & $12.1 \mathrm{~km} \mathrm{WNW}$ of $200 \mathrm{West}$ \\
\hline |02120205272 & & $02 / 12 / 02$ & 05:27:49.61 & $46 \mathrm{~N} 34.67$ & 119W42.44 & 14.37 & -0.2 & $3 / 05$ & 127 & 5 & 0.04 & $\mathrm{AD}$ & $5.8 \mathrm{~km} \mathrm{WNW}$ of $200 \mathrm{West}$ \\
\hline $\mid 02120622321$ & $\mathrm{X}$ & $02 / 12 / 06$ & $22: 32: 38.39$ & 46N10.11 & 119W28.62 & 0.63 & & $9 / 09$ & 260 & 14 & 0.11 & $\mathrm{BD}$ & 19.2 km SW of Richland \\
\hline $\mid 02121417035$ & & $02 / 12 / 14$ & $17: 04: 20.95$ & $46 \mathrm{~N} 20.29$ & 119W32.89 & 16.58 & 0.6 & $15 / 16$ & 99 & 6 & 0.07 & $\mathrm{AB}$ & $18.2 \mathrm{~km} \mathrm{SW}$ of 400 Area \\
\hline 02122206575 & & $02 / 12 / 22$ & 06:58:16.19 & $46 \mathrm{~N} 22.93$ & 119W02.73 & 4.85 & 0.3 & $6 / 09$ & 149 & 19 & 0.17 & $\mathrm{BC}$ & $16.8 \mathrm{~km} \mathrm{NNE}$ of Pasco \\
\hline 02122211403 & & $02 / 12 / 22$ & $11: 40: 50.99$ & $46 \mathrm{~N} 19.32$ & 119W30.02 & 4.09 & 0.6 & $8 / 10$ & 110 & 5 & 0.76 & DB & $16.6 \mathrm{~km} \mathrm{WNW}$ of Richland \\
\hline 02122211412 & & $02 / 12 / 22$ & $11: 41: 28.31$ & $46 \mathrm{~N} 16.17$ & 119W28.04 & 10.95 & 0.6 & $10 / 16$ & 287 & 3 & 0.14 & $\mathrm{AD}$ & $13.6 \mathrm{~km} \mathrm{~W}$ of Richland \\
\hline $\mid 02122211542$ & & $02 / 12 / 22$ & $11: 54: 39.64$ & $46 \mathrm{~N} 15.72$ & 119W28.27 & 10.60 & 0.3 & $8 / 13$ & 289 & 4 & 0.04 & $\mathrm{AD}$ & $14.0 \mathrm{~km} \mathrm{~W}$ of Richland \\
\hline $\mid 02122911410$ & & $02 / 12 / 29$ & $11: 41: 22.66$ & $46 \mathrm{~N} 43.48$ & 119W04.92 & 10.83 & 1.3 & $8 / 19$ & 124 & 13 & 0.08 & $\mathrm{AB}$ & $13.1 \mathrm{~km}$ SSE of Othello \\
\hline $\mid 02123022330$ & $\mathrm{X}$ & $02 / 12 / 30$ & $22: 33: 31.16$ & $46 \mathrm{~N} 16.10$ & 119W23.66 & 0.02 & & $13 / 13$ & 229 & 4 & 0.10 & $\mathrm{AD}$ & $8.1 \mathrm{~km}$ WSW of Richland \\
\hline 03011421583 & $\mathrm{X}$ & $03 / 01 / 14$ & $21: 58: 59.57$ & $46 \mathrm{~N} 15.82$ & 119W23.58 & 0.07 & & $13 / 13$ & 232 & 5 & 0.13 & $\mathrm{AD}$ & $8.1 \mathrm{~km}$ WSW of Richland \\
\hline $\mid 03012400230$ & $\mathrm{P}$ & $03 / 01 / 24$ & $00: 23: 29.86$ & $46 \mathrm{~N} 15.94$ & $119 \mathrm{~W} 23.48$ & 3.12 & & $12 / 12$ & 129 & 5 & 0.09 & $\mathrm{AB}$ & $7.9 \mathrm{~km}$ WSW of Richland \\
\hline
\end{tabular}


Table 3.2. (Contd.)

\begin{tabular}{|c|c|c|c|c|c|c|c|c|c|c|c|c|c|}
\hline "Event ID & Type & Date & Time & Latitutde & Longitude & "Depth & Mag & "MS/NP & Gap & Dmin & "RMS & $\overline{Q Q}$ & Location \\
\hline 03012611344 & & $03 / 01 / 26$ & $11: 35: 09.10$ & 46N29.40 & 119W20.58 & 0.35 & 1.0 & $8 / 08$ & 124 & 7 & 0.08 & $\mathrm{AB}$ & $6.2 \mathrm{~km} \mathrm{~N}$ of 400 Area \\
\hline $\mid 03012821092$ & $\mathrm{X}$ & $03 / 01 / 28$ & $21: 09: 50.34$ & $46 \mathrm{~N} 08.73$ & $119 \mathrm{~W} 11.82$ & 0.05 & & $15 / 15$ & 188 & 21 & 0.18 & $\mathrm{BD}$ & $8.6 \mathrm{~km} \mathrm{SW}$ of Kennewick \\
\hline 03020416331 & & $03 / 02 / 04$ & $16: 33: 39.63$ & $46 \mathrm{~N} 27.62$ & 119W01.21 & 15.76 & 1.7 & $21 / 21$ & 113 & 14 & 0.14 & $\mathrm{AB}$ & $22.9 \mathrm{~km}$ ENE of 300 Area \\
\hline $\mid 03021202012$ & & $03 / 02 / 12$ & $02: 01: 47.14$ & $46 \mathrm{~N} 36.18$ & 119W45.14 & 16.56 & 0.8 & $15 / 18$ & 165 & 1 & 0.07 & $\mathrm{AC}$ & $10.1 \mathrm{~km} \mathrm{WNW}$ of $200 \mathrm{West}$ \\
\hline 03021222082 & $\mathrm{X}$ & $03 / 02 / 12$ & $22: 08: 42.73$ & $46 \mathrm{~N} 08.74$ & 119W11.13 & 0.84 & & $14 / 14$ & 158 & 20 & 0.13 & $\mathrm{BC}$ & $8.0 \mathrm{~km} \mathrm{SW}$ of Kennewick \\
\hline $\mid 03021417463$ & & $03 / 02 / 14$ & $17: 46: 54.14$ & $46 \mathrm{~N} 36.21$ & 119W51.58 & 6.54 & 0.3 & $8 / 09$ & 217 & 7 & 0.06 & $\mathrm{AD}$ & $17.7 \mathrm{~km} \mathrm{WNW}$ of $200 \mathrm{West}$ \\
\hline $\mid 03021621242$ & & $03 / 02 / 16$ & $21: 24: 44.95$ & $46 \mathrm{~N} 33.92$ & 119W53.34 & 8.15 & 0.1 & $3 / 06$ & 310 & 11 & 0.09 & $\mathrm{BD}$ & $19.3 \mathrm{~km} \mathrm{~W}$ of 200 West \\
\hline $\mid 03021807232$ & & $03 / 02 / 18$ & $07: 23: 42.64$ & $46 \mathrm{~N} 27.18$ & 119W37.09 & 17.21 & -0.1 & $8 / 11$ & 128 & 3 & 0.07 & $\mathrm{AB}$ & $11.8 \mathrm{~km} \mathrm{~S}$ of $200 \mathrm{West}$ \\
\hline $\mid 03021822404$ & $\mathrm{P}$ & $03 / 02 / 18$ & $22: 41: 10.59$ & 46N59.69 & $119 \mathrm{~W} 12.89$ & 0.84 & & $8 / 08$ & 153 & 6 & 0.07 & $\mathrm{AC}$ & $15.6 \mathrm{~km}$ SSE of Moses Lake \\
\hline 03030910315 & & $03 / 03 / 09$ & $10: 32: 20.29$ & $46 \mathrm{~N} 44.93$ & $119 \mathrm{~W} 22.18$ & 3.15 & 0.7 & $13 / 14$ & 95 & 5 & 0.06 & $\mathrm{AB}$ & $17.8 \mathrm{~km}$ WSW of Othello \\
\hline 03031305552 & & $03 / 03 / 13$ & $05: 55: 39.58$ & $46 \mathrm{~N} 57.15$ & 119W07.57 & 3.88 & 0.5 & $6 / 08$ & 161 & 2 & 0.14 & $\mathrm{BC}$ & $14.3 \mathrm{~km}$ NNE of Othello \\
\hline 03031411402 & & $03 / 03 / 14$ & $11: 40: 45.59$ & $46 \mathrm{~N} 24.24$ & $119 \mathrm{~W} 23.15$ & 16.58 & 0.6 & $16 / 19$ & 129 & 2 & 0.12 & $\mathrm{AB}$ & $4.1 \mathrm{~km} \mathrm{SSW}$ of 400 Area \\
\hline 03031801175 & & $03 / 03 / 18$ & $01: 18: 22.69$ & $46 \mathrm{~N} 50.82$ & $119 \mathrm{~W} 44.10$ & 2.36 & 1.8 & $26 / 28$ & 66 & 11 & 0.11 & $\mathrm{AC}$ & $22.6 \mathrm{~km}$ ESE of Vantage \\
\hline $\mid 03031903190$ & & $03 / 03 / 19$ & $03: 19: 14.81$ & $46 \mathrm{~N} 46.24$ & 119W55.48 & 0.04 & 0.8 & $6 / 06$ & 109 & 5 & 0.09 & $\mathrm{AC}$ & $21.3 \mathrm{~km}$ SSE of Vantage \\
\hline 03031904385 & & $03 / 03 / 19$ & $04: 39: 20.17$ & $46 \mathrm{~N} 39.59$ & $119 \mathrm{~W} 39.25$ & 16.10 & 0.0 & $12 / 15$ & 120 & 6 & 0.07 & $\mathrm{AB}$ & $4.8 \mathrm{~km} \mathrm{WNW}$ of $100-\mathrm{K}$ Area \\
\hline $\mid 03032011414$ & & $03 / 03 / 20$ & $11: 42: 07.13$ & $46 \mathrm{~N} 28.92$ & 119W35.84 & 12.46 & -0.1 & $7 / 10$ & 114 & 5 & 0.08 & $\mathrm{AB}$ & $9.0 \mathrm{~km} \mathrm{SSE}$ of $200 \mathrm{West}$ \\
\hline $\mid 03032115185$ & & $03 / 03 / 21$ & $15: 19: 20.34$ & $46 \mathrm{~N} 29.06$ & $119 \mathrm{~W} 35.80$ & 10.66 & -0.1 & $7 / 08$ & 90 & 5 & 0.03 & $\mathrm{AB}$ & $8.8 \mathrm{~km}$ SSE of $200 \mathrm{West}$ \\
\hline $\mid 03032115193$ & & $03 / 03 / 21$ & $15: 19: 33.94$ & $46 \mathrm{~N} 29.28$ & 119W35.53 & 9.05 & -0.3 & $7 / 09$ & 88 & 5 & 0.04 & $\mathrm{AB}$ & $8.5 \mathrm{~km}$ SSE of $200 \mathrm{West}$ \\
\hline $\mid 03032323322$ & & $03 / 03 / 23$ & $23: 32: 44.39$ & $46 \mathrm{~N} 39.72$ & $119 \mathrm{~W} 36.75$ & 0.25 & 0.0 & $6 / 06$ & 134 & 6 & 0.10 & $\mathrm{AC}$ & $2.5 \mathrm{~km} \mathrm{NNW}$ of $100-\mathrm{K}$ Area \\
\hline 03032323323 & & $03 / 03 / 23$ & $23: 32: 46.72$ & $46 \mathrm{~N} 39.81$ & 119W36.93 & 0.03 & 1.9 & $18 / 19$ & 89 & 6 & 0.07 & $\mathrm{AB}$ & $2.8 \mathrm{~km} \mathrm{NNW}$ of $100-\mathrm{K}$ Area \\
\hline $\mid 03032401584$ & & $03 / 03 / 24$ & $01: 57: 22.21$ & $46 \mathrm{~N} 46.75$ & 119W57.69 & 0.02 & 0.2 & $8 / 09$ & 190 & 6 & 0.18 & $\mathrm{BD}$ & $20.0 \mathrm{~km} \mathrm{~S}$ of Vantage \\
\hline 03032419435 & & $03 / 03 / 24$ & $19: 44: 19.75$ & $46 \mathrm{~N} 39.73$ & 119W36.79 & 1.69 & 1.6 & $16 / 17$ & 64 & 6 & 0.05 & $\mathrm{AB}$ & $2.6 \mathrm{~km} \mathrm{NNW}$ of $100-\mathrm{K}$ Area \\
\hline 03033014200 & & $03 / 03 / 30$ & $14: 20: 28.50$ & $46 \mathrm{~N} 35.17$ & 119W20.77 & 14.09 & -0.4 & $10 / 15$ & 115 & 3 & 0.09 & $\mathrm{AB}$ & $14.8 \mathrm{~km}$ ENE of 200 East \\
\hline
\end{tabular}




\section{Explanation of Table 3.2}

Event ID: The Earthworm Recording System creates the identification number. XPED uses the year, month, day and time to create a unique number for each event.

Type: $\quad \mathrm{P}$ is Probable Blast; $\mathrm{X}$ is Confirmed Blast; $\mathrm{F}$ is Felt Earthquake; $\mathrm{S}$ is surficial event (rockslide, avalanche) and not a explosion or tectonic earthquake; blank is local earthquake.

Date: The year and day of the year in Universal Time Coordinated (UTC). UTC is used throughout this report unless otherwise indicated.

Time: The origin time of the earthquake given in UTC. To covert UTC to Pacific Standard Time, subtract eight hours; to Pacific Daylight Time, subtract seven hours.

Latitude: North latitude, in degrees and minutes, of the earthquake epicenter.

Longitude: West longitude, in degrees and minutes, of the earthquake epicenter.

Depth: The depth of the earthquake in kilometers $(\mathrm{km})$.

Mag: The magnitude is expressed as Coda-Length magnitude $\mathrm{M}_{\mathrm{c}}$, an estimate of local magnitude $\mathrm{M}_{\mathrm{L}}$ (Richter 1958). If magnitude is blank a determination was not made.

NS/NP: Number of stations/number of phases used in the solutions.

Gap: Azimuthal gap. The largest angle (relative to the epicenter) containing no stations.

DMIN: The distance from the earthquake epicenter to the closest station

RMS: $\quad$ The root-mean-square residual (observed arrival times minus the predicted arrival times) at all stations used to locate the earthquake. It is only useful as a measure of quality of the solution when five or more well-distributed stations are used in the solution. Good solutions are normally characterized by RMS values of less than about 0.3 seconds.

Q: $\quad$ The Quality Factors indicate the general reliability of the solution/location (A is best quality, D is worst). See Section 3.3 of this report: Quality Factors.

\subsection{Quality Factors (Q)}

XPED assigns a two-letter Quality factor (Table 3.2) that indicates the general reliability of the solution (A is best quality, $\mathbf{D}$ is worst). Similar quality factors are used by the USGS for events located with the computer program HYPO71. The first letter of the quality code is a measure of the hypocenter quality based primarily on travel time residuals. For example: Quality A requires a root-mean-square residual (RMS) less than 0.15 seconds while a RMS of 0.5 seconds or more is $\mathbf{D}$ quality (other estimates of the location uncertainty also affect this quality parameter). The second letter of the quality code is 
related to the spatial distribution of stations that contribute to the event's location, including the number of stations (NS), the number of p-wave and s-wave phases (NP), the largest gap in event-station azimuth distribution (GAP), and the closest distance from the epicenter to a station (DMIN). Quality A requires a solution with $\mathbf{N P}>8, \mathbf{G A P}<90^{\circ}$, and DMIN $<5 \mathrm{~km}$ (or the hypocenter depth if it is greater than $5 \mathrm{~km}$ ). If $\mathbf{N P} \leq 5$, GAP $>180^{\circ}$, or DMIN $>50 \mathrm{~km}$, the solution is assigned Quality $\mathbf{D}$. 


\subsection{Geology and Tectonic Analysis}

The Hanford Site lies within the Columbia Basin, which is an intermontane basin between the Cascade Range and the Rocky Mountains that is filled with Cenozoic volcanic rocks and sediments. This basin forms the northern part of the Columbia Plateau physiographic province (Fenneman 1931) and the Columbia River flood-basalt province (Reidel and Hooper 1989). In the central and western parts of the Columbia Basin, the Columbia River Basalt Group (CRBG) overlies Tertiary continental sedimentary rocks and is overlain by late Tertiary and Quaternary fluvial and glaciofluvial deposits (Campbell 1989; Reidel et al. 1989, 1994; DOE 1988). In the eastern part, a thin $(<100 \mathrm{~m})$ sedimentary unit separates the basalt and underling crystalline basement and a thin $(<10 \mathrm{~m})$ veneer of eolian sediments overlies the basalt (Reidel et al. 1989, 1994).

The Columbia Basin has two structural subdivisions or subprovinces: the Yakima Fold Belt and the Palouse Slope. The Yakima Fold Belt includes the western and central parts of the Columbia Basin and is a series of anticlinal ridges with major thrust faults along the northern flanks and synclinal valleys (Figure 4.1) (Reidel and Fecht 1994a, 1994b). The Palouse Slope is the eastern part of the basin and is less deformed than the Yakima Fold Belt with only a few faults and low amplitude, long wavelength folds on an otherwise gently westward dipping paleoslope. Figure 4.2 shows north-south and east-west cross sections through the Columbia Basin based on surface mapping (Reidel and Fecht 1994a, 1994b), deep boreholes (Reidel et al. 1994), geophysical data (Rohay et al. 1985; DOE 1988), and magnetotelluric data obtained as part of BWIP (DOE 1988).

\subsection{Earthquake Stratigraphy}

Studies of seismicity at the Hanford Site have shown that the seismic activity is related to crustal stratigraphy (layers of rock types) (Rohay et al. 1985; DOE 1988). The main geologic units important to earthquakes at Hanford and the surrounding area are:

The Miocene Columbia River Basalt Group (CRBG)

Pre-basalt sediments of Paleocene, Eocene, and Oligocene age

The crystalline basement consisting of 2 layers composed of Precambrian and Paleozoic craton

Mesozoic accreted terranes.

\subsection{Geologic Structure Beneath the Monitored Area}

Between the late 1950s and the early 1980s, deep boreholes were drilled for hydrocarbon exploration in the Columbia Basin. These boreholes provided accurate measurements of the physical properties of the CRBG and the pre-basalt sediments (Reidel et al. 1989, 1994), but the thickness of the pre-basalt sediments and nature of the crystalline basement are still poorly understood. The difference between the 


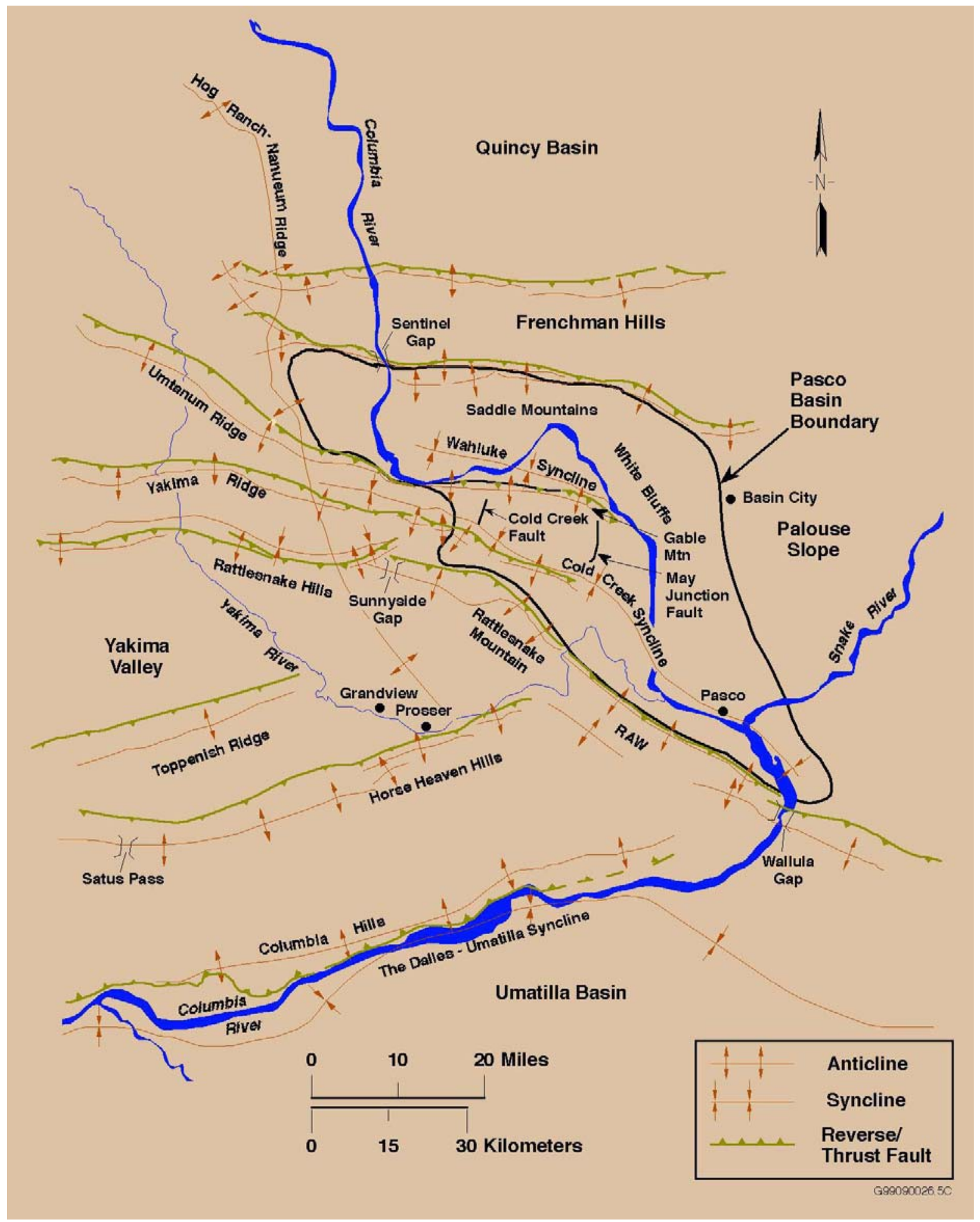

Figure 4.1. Tectonic Map of Columbia Basin Showing Major Seismic Source Structures 

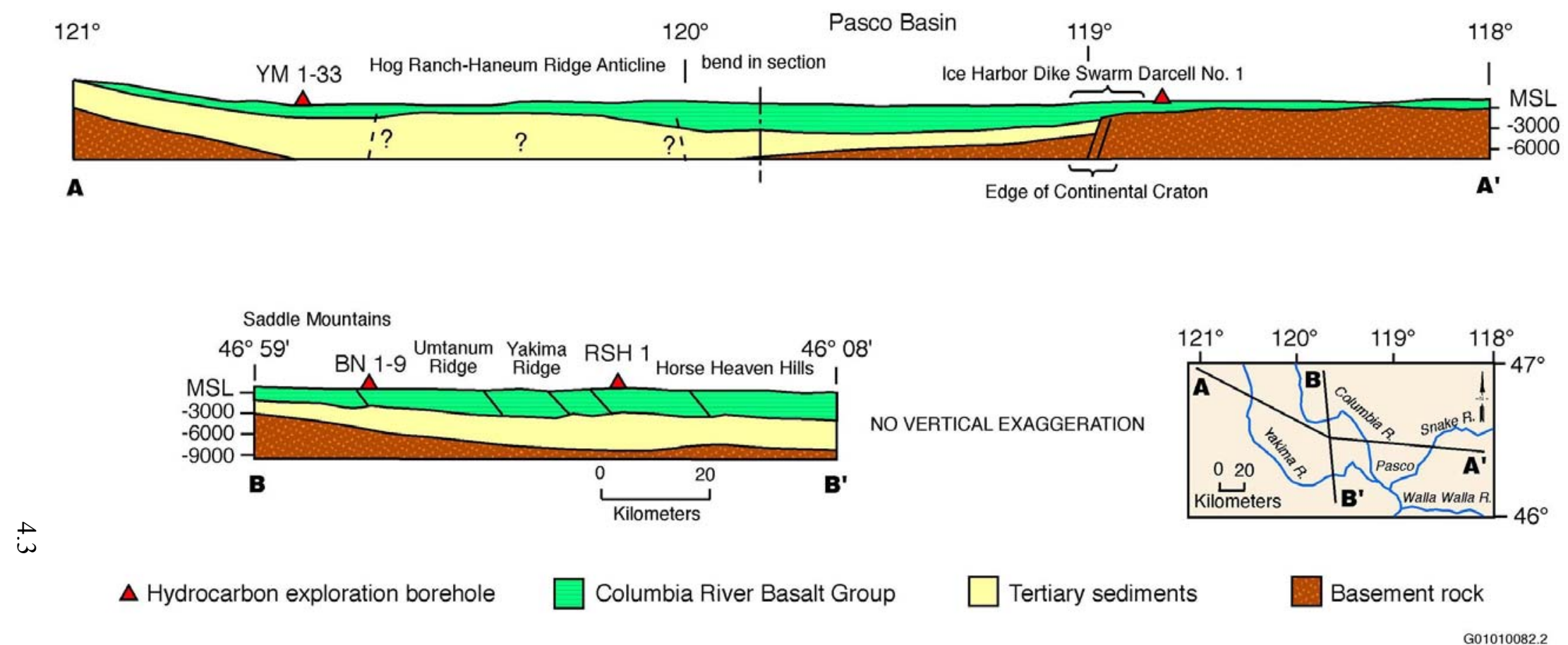

Figure 4.2. Geologic Cross Sections Through the Columbia Basin (Reidel et al. 1994) 
Table 4.1. Thicknesses of Stratigraphic Units in the Monitoring Area

\begin{tabular}{||l|c|c|c|c||}
\hline \multicolumn{1}{|c|}{ Stratigraphy } & North & South & East & West \\
\hline \hline $\begin{array}{l}\text { Columbia River Basalt Group (includes } \\
\text { suprabasalt sediments) }\end{array}$ & $3.0 \mathrm{~km}$ & $4.5 \mathrm{~km}$ & $2.2 \mathrm{~km}$ & $4.2 \mathrm{~km}$ \\
\hline Pre-basalt Sediments & $3.0 \mathrm{~km}$ & $>4.5 \mathrm{~km}$ & 0 & $>6.0 \mathrm{~km}$ \\
\hline
\end{tabular}

thicknesses listed in Table 4.1 and the thicknesses of the crustal layers in the velocity model in Table 3.1 reflect data specific to UW's crustal velocity model for eastern Washington. Table 4.1 is derived from Reidel et al. (1994) and was developed for the geologic interpretation in this report. The thicknesses of these units are variable across the monitored area. Table 4.1 summarizes the approximate thickness at the borders of the monitored area.

The thickness of the basalt and the pre-basalt sediments varies as a result of different tectonic environments. The western edge of the North American craton (late Precambrian/Paleozoic continental margin and Precambrian craton) is located in the eastern portion of the monitored area (Reidel et al. 1994). The stratigraphy on the craton consists of CRBG overlying crystalline basement; the crystalline basement is continental crustal rock that underlies much of the western North America. The stratigraphy west of the craton consists of 4 to $5 \mathrm{~km}$ of CRBG overlying at least $6 \mathrm{~km}$ of pre-basalt sediments. This in turn overlies accreted terranes of Mesozoic age. The area west of the craton was subsiding during the Eocene and Oligocene, accumulating great thickness of pre-CRBG sediments. Continued subsidence in this area during the Miocene resulted in thicker CRBG compared to that on the craton. Subsidence continues today but at a greatly reduced rate (Reidel et al. 1994).

\subsection{Tectonic Pattern}

Studies have concluded that earthquakes can occur in the following six different tectonic environments (earthquake sources) at the Hanford Site (Geomatrix 1996).

- Major Geologic Structures. Reverse/thrust faults in the CRBG associated with major anticlinal ridges such as Rattlesnake Mountain, Yakima Ridge, and Umtanum Ridge could produce some of the largest earthquakes.

- Secondary faults. These faults are typically smaller $(1-20 \mathrm{~km})$ than the main reverse/thrust faults that occur along the major anticlinal ridges (up to $100 \mathrm{~km}$ ). Secondary faults can be segment boundaries (tear faults) and small faults of any orientation that formed along with the main structure.

- Swarm areas. Small geographic areas not known to contain any geologic structures produce clusters of events (swarms), usually in the CRBG in synclinal valleys. These clusters consist of a series of small shocks with no outstanding principal event. Swarms occur over a period of days or months and the events may number into the hundreds and then quit, only to start again at a later date. This differs from the sequence of foreshocks, mainshock, and trailing-off aftershocks that have the same epicenter or are associated with the same fault system. In the past, swarms were thought to 
occur only in the Columbia River Basalt Group. Most swarm areas are in the basalt but swarm events also appear to occur in all geologic layers. However, typically a swarm event at a specific time is usually restricted to one layer. There are seven earthquake swarm areas that we recognize in the monitoring area (Figure 4.3) but this list will be updated as new swarm areas develop. The Saddle Mountains swarm area, Wooded Island swarm area, Wahluke swarm area, Coyote Rapids swarm area, and Horse Heaven Hills swarm area are typically active at one time or another during the year. The other earthquake swarm areas are active less frequently.

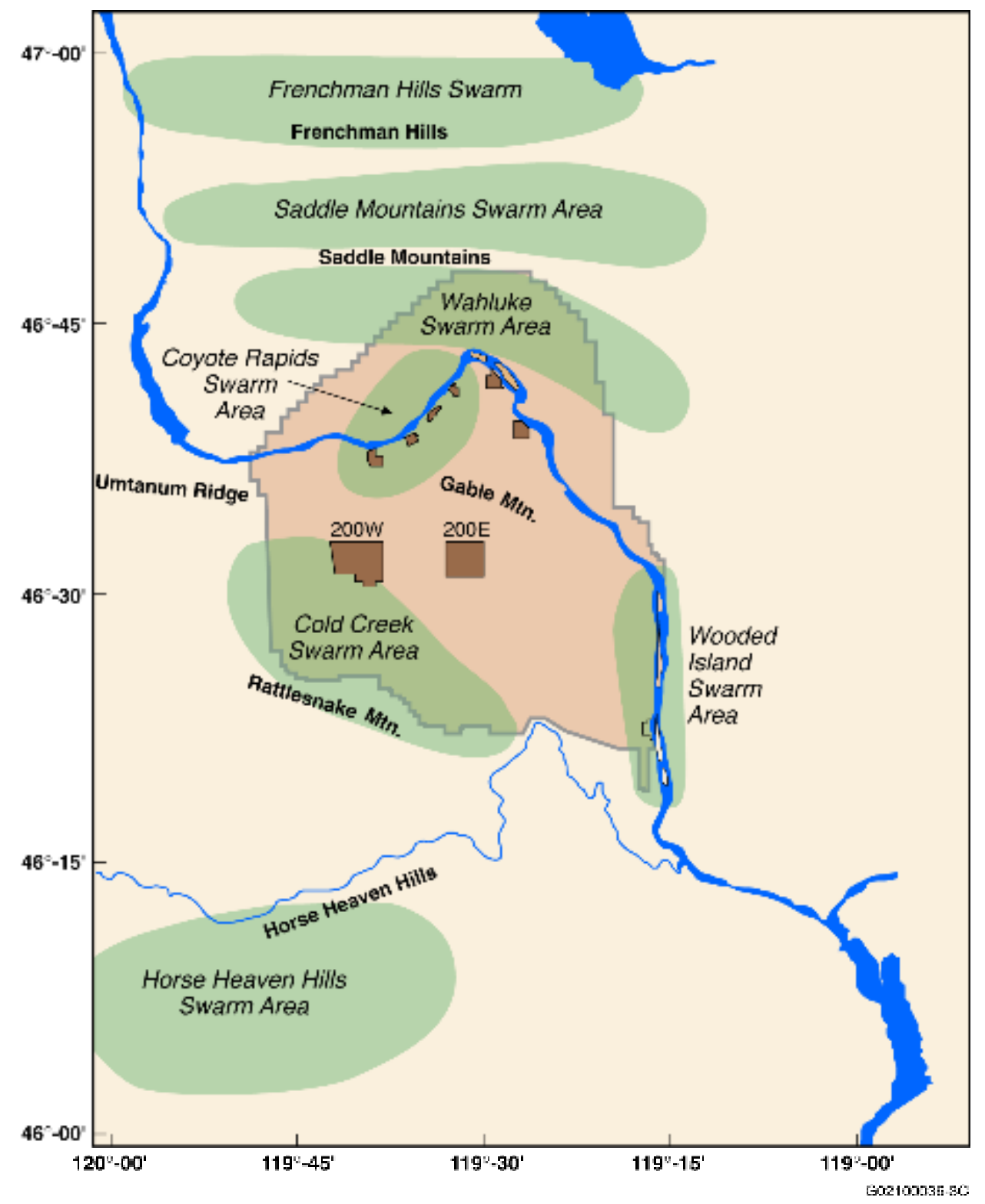

Figure 4.3. Locations of Known Earthquake Swarm Areas in the Hanford Monitoring Network Area 
- The entire Columbia Basin. The entire basin, including the Hanford Site, could produce a "floating" earthquake. A floating earthquake is one that, for seismic design purposes, can happen anywhere in a tectonic province and is not associated with any known geologic structure. Seismic Monitoring classifies it as a random event for purposes of seismic design and vibratory ground motion studies.

- Basement source structures. Studies (Geomatrix 1996) suggest that major earthquakes can originate in tectonic structures in the crystalline basement. Because little is known about geologic structures in the crystalline basement beneath the Hanford Site, earthquakes cannot be directly tied to a mapped fault. Earthquakes occurring in the crystalline basement without known sources are treated as random events.

- The Cascadia Subduction Zone. This source has been postulated to be capable of producing a magnitude 9 earthquake. Because this source is along the western boundary of Washington State and outside the HSN, the Cascadia Subduction Zone is not an earthquake source that is monitored at the Hanford Site, so subduction zone earthquakes are not reported here. Because any earthquake along the Cascadia Subduction zone can have a significant impact on the Hanford Site or can be felt like the February 2001 Nisqually earthquake, UW monitors and reports on this earthquake source for the DOE. Ground motion from any moderate or larger Cascadia Subduction Zone earthquake is detected by Hanford SMAs and reported (see Section 5.0).

\subsection{Depth of Earthquakes}

Since records have been kept, most of the earthquakes at the Hanford Site have originated in the CRBG layer. The crystalline basement has had the next greatest amount of earthquakes followed by the pre-basalt sediments. The stratigraphic units for local earthquakes recorded during the first and second quarters of FY 2003 are listed in Table 4.2.

\subsection{Tectonic Activity}

\subsubsection{Second Quarter Summary}

Twenty earthquakes occurred in the Hanford monitoring area during the second quarter of FY 2003 (January 1, 2003 through March 31, 2003) (Table 4.3) (Figure 4.4). This section summarizes the earthquake activity for that period of time. More detailed descriptions of this activity are given below.

Table 4.2. Number of Local Earthquakes Occurring in Stratigraphic Units

\begin{tabular}{||l|c|c|c|c|c||}
\hline \multicolumn{1}{|c|}{ Unit } & First Quarter & Second Quarter & $\begin{array}{c}\text { Third } \\
\text { Quarter }\end{array}$ & Fourth Quarter & \multicolumn{1}{c||}{ FY 2002 } \\
\hline \hline Basalt & 6 & 9 & - & - & $15(30.6 \%)$ \\
\hline Pre-basalt Sediments & 4 & 2 & - & - & $6(12.3 \%)$ \\
\hline Crystalline Basement & 19 & 9 & - & - & $28(57.1 \%)$ \\
\hline Total & 29 & 20 & - & - & 49 \\
\hline
\end{tabular}


Table 4.3. Summary of Earthquake Locations for FY 2003

\begin{tabular}{|c|c|c|c|c|c|c|}
\hline \multicolumn{2}{|c|}{ Seismic Sources } & $\begin{array}{c}\text { First } \\
\text { Quarter } \\
\text { 10/01- 12/30 }\end{array}$ & $\begin{array}{c}\text { Second } \\
\text { Quarter } \\
\text { 1/01 - 3/31 }\end{array}$ & $\begin{array}{c}\text { Third } \\
\text { Quarter } \\
\text { 4/01 - 6/30 }\end{array}$ & $\begin{array}{c}\text { Fourth } \\
\text { Quarter } \\
\text { 7/01 - 9/30 }\end{array}$ & FY 2003 \\
\hline \multicolumn{2}{|c|}{ Geologic Structure } & 1 & 2 & - & - & $3(6.1 \%)$ \\
\hline \multirow{8}{*}{$\begin{array}{l}\text { Swarm } \\
\text { Areas }\end{array}$} & Frenchman Hills & 0 & 1 & - & - & $1(2.0 \%)$ \\
\hline & $\begin{array}{l}\text { Saddle } \\
\text { Mountains/ } \\
\text { Royal Slope }\end{array}$ & 3 & 1 & - & - & $4(8.2 \%)$ \\
\hline & Coyote Rapids & 1 & 3 & - & - & $4(8.2 \%)$ \\
\hline & Wooded Island & 0 & 0 & - & - & 0 \\
\hline & Wahluke Slope & 0 & 1 & - & - & $1(2.0 \%)$ \\
\hline & Cold Creek & 0 & 0 & - & - & 0 \\
\hline & $\begin{array}{l}\text { Horse Heaven } \\
\text { Hills }\end{array}$ & 2 & 0 & - & - & $2(4.1 \%)$ \\
\hline & Total for swarms & 6 & 6 & - & - & $12(24.5 \%)$ \\
\hline \multicolumn{2}{|c|}{ Random Events } & 22 & 12 & - & - & $34(69.4 \%)$ \\
\hline \multicolumn{2}{|c|}{ Total for all earthquakes } & 29 & 20 & - & - & 49 \\
\hline
\end{tabular}

\subsubsection{Depth of Earthquakes}

During the second quarter of FY 2003, 45\% of the earthquakes occurred in the Columbia River Basalt Group, $10 \%$ of the earthquakes occurred in the underlying pre-basalt sediments, and $45 \%$ of the earthquakes occurred in the crystalline basement.

\subsubsection{Location of Earthquakes}

During the second quarter of FY 2003, six events (30\% of the earthquakes) were classified as swarm events. The Frenchman Hills, Saddle Mountains, Coyote Rapids and Wahluke Slope swarm areas were the active swarm areas.

Two events were classified as having some association with major geologic structures. These earthquakes occurred in basalt in the Saddle Mountains structure (Figure 4.1).

Twelve events (60\% of the earthquakes) were classified as random events. Earthquakes typically are classified as random if they occur below the Columbia River Basalt Group. Very little is known about geologic structures in the pre-basalt sediments and crystalline basement so any interpretations are speculative at this time. An earthquake also can be classified as a random event if it occurs in the basalt but is not located near any known geologic structure. During the second quarter, nine events occurred in the crystalline basement. One random event occurred in the basalt and two random events occurred in the pre-basalt sediments. 


\subsubsection{Second Quarter Earthquakes of FY 2003}

\subsubsection{Major Anticlinal Ridges}

During the second quarter of FY 2003, we interpret two seismic events to have occurred on a major geologic structure. On March $18^{\text {th }}$, a small $\left(1.8 \mathrm{M}_{\mathrm{c}}\right)$, shallow earthquake occurred at Sentinel Gap in the Saddle Mountains (Figure 4.1). A second event occurred at the same location on March $24^{\text {th }}$ and had a magnitude of $1.9 \mathrm{M}_{\mathrm{c}}$. These events were located in the CRBG and are interpreted to be associated with the Saddle Mountains anticline and possibly a small tear fault that is present in Sentinel Gap (Reidel 1984, 1988).

\subsubsection{Earthquake Swarm Areas}

During the second quarter of FY 2003, we interpret 6 seismic events to have occurred in swarm areas (Figure 4.3). The Frenchman Hills, Saddle Mountains, Coyote Rapids and Wahluke Slope swarm areas were active.

\subsection{Frenchman Hills Swarm Area}

One earthquake (Figure 4.4) occurred at the eastern end of the Frenchman Hills swarm area on March $13^{\text {th }}$. The earthquake was small $\left(0.5 \mathrm{M}_{\mathrm{c}}\right)$ and was in the basalt.

\subsection{Saddle Mountains Swarm Area}

During the second quarter of FY 2003, one event occurred in the Saddle Mountains swarm area (Figure 4.4). The event occurred on March $18^{\text {th }}$ and had a magnitude of $1.8 \mathrm{M}_{\mathrm{c}}$. The event occurred in the basalt and was at the same location where previous earthquakes had occurred on October 12, 2002 and October 22, 2002.

\subsection{Coyote Rapids Swarm Area}

Three small events $\left(<2.0 \mathrm{M}_{\mathrm{c}}\right)$ occurred in the Coyote Rapids earthquake swarm during the second quarter of FY 2003. The first two events occurred on March $23^{\text {rd }}$ and the third event occurred the following day. All three events occurred in the basalt and in an area that had been active in the past. Another event occurred there on March $17^{\text {th }}$ but this event was in the crystalline basement and is classified as a random event because of its depth. However, we have noticed that activity in a swarm area may not be confined to just one layer. If a consistent pattern of earthquakes occurring in several stratigraphic layers can be established here, this deep event may be reclassified as a swarm event in the future.

\subsection{Wahluke Slope Swarm Area}

One event occurred in the Wahluke Slope swarm area on March $9^{\text {th }}$. The event was small $\left(0.7 \mathrm{M}_{\mathrm{c}}\right)$ and occurred in the basalt along the eastern edge of an area where earthquakes have occurred in the past several years. Four events occurred there in FY 2002 and 13 events occurred there in FY 2001. 


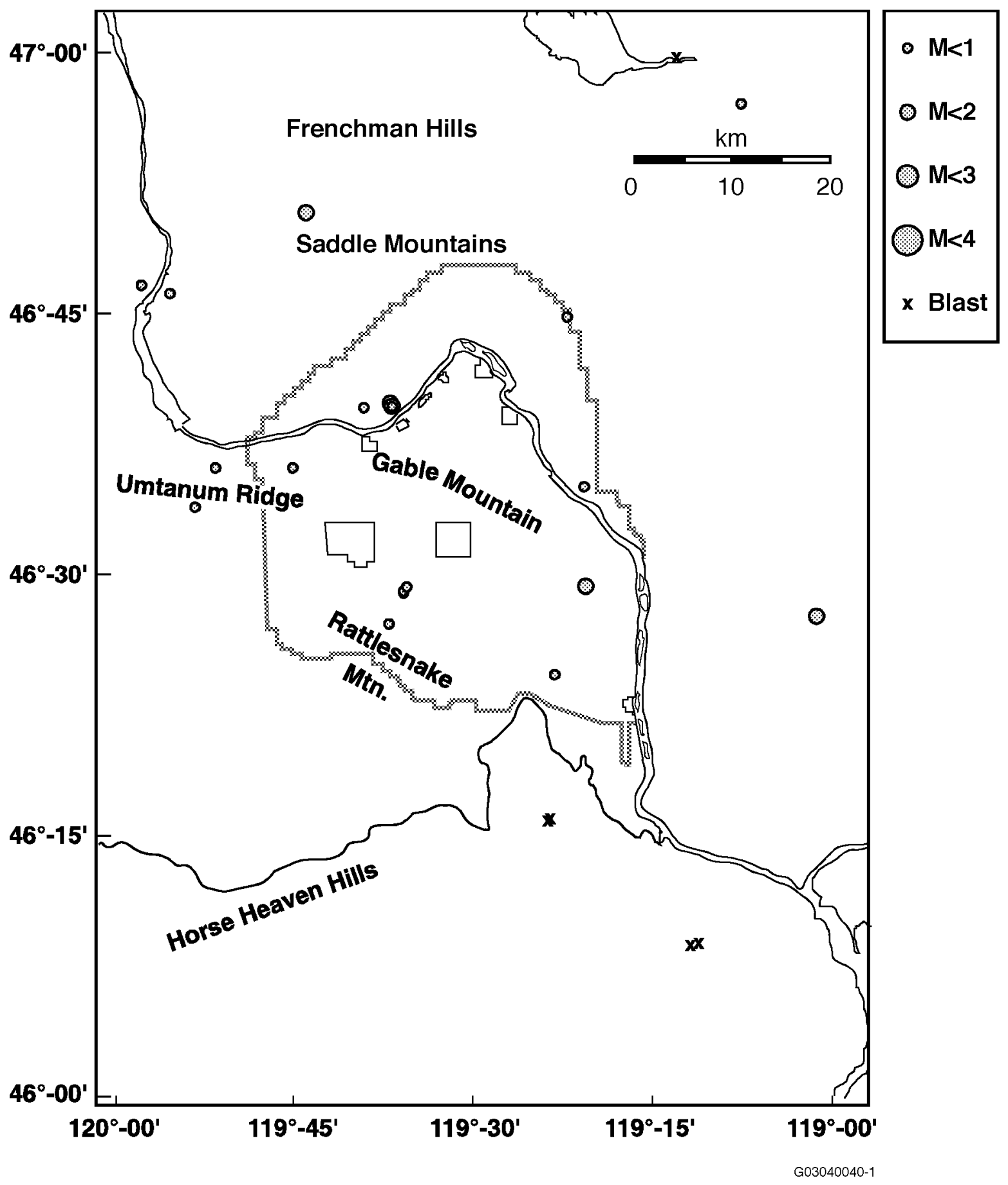

Figure 4.4. All Earthquakes Recorded in the Hanford Monitoring Area Between January 1, 2003 and March 31, 2003 (Coda Length Magnitude $\left(M_{c}\right)$ scale is shown at the side of the map) 


\subsubsection{Random or Floating Events}

During the second quarter of FY 2003, we interpret twelve random events to have occurred in the monitoring area. One was in the basalt, two were in pre-basalt sediments and nine were in the crystalline basement. Events that occurred in the pre-basalt sediments and in the crystalline basement are typically classified as random events because there are no known geologic structures that have been identified in the rocks that occur below the Columbia River Basalt Group. However, we now recognize that some events that occur at depths that places them in the pre-basalt sediments and crystalline basement occur in patterns that fit our definition of earthquake swarms (Section 4.4). Those events are now reported in the appropriate sections on earthquake swarms.

The first random event for the second quarter of FY 2003 was on January $25^{\text {th }}$ and occurred in the basalt on the east side of the Hanford Site in the Cold Creek syncline. It was a small earthquake $\left(1.0 \mathrm{M}_{\mathrm{c}}\right)$ that was located east of the May Junction fault (Fig. 4.1) in one of the larger basins that developed along the Cold Creek syncline.

A small earthquake $\left(1.7 \mathrm{M}_{\mathrm{c}}\right)$ occurred on February $4^{\text {th }}$ in Esquatzel coulee near the town of Eltopia. This event was on the Palouse Slope and was located in the crystalline basement. It is classified as random because of its depth and the absence of any known geologic structures in the area.

On February $12^{\text {th }}$ a small event $(0.8 \mathrm{Mc})$ occurred in the crystalline basement beneath Umtanum Ridge. This event is classified as random because it was in the crystalline basement. However, during the first quarter of FY 2003, three events occurred at the same location. Two were also in the crystalline basement and the third was in the prebasalt sediments. Two events also occurred at this location during FY2002. One event was in the crystalline basement and one was in the pre-basalt sediments. Another small event $\left(0.3 \mathrm{M}_{\mathrm{c}}\right)$ occurred on February $14^{\text {th }}$ about $4 \mathrm{~km}$ west of the February $12^{\text {th }}$ event. It was located in the pre-basalt sediments and therefore is classified as a random event.

On February $16^{\text {th }}$ a small event $(0.1 \mathrm{Mc})$ occurred on Yakima Ridge south of the February $12^{\text {th }}$ and $14^{\text {th }}$ events on Umtanum Ridge. This earthquake occurred in the prebasalt sediments.

On February $18^{\text {th }}$ a small event (approximately $0 \mathrm{M}_{\mathrm{c}}$ ) occurred in the Benson Ranch syncline north of the Rattlesnake Mountain structure and south of Yakima Ridge. Two events occurred nearby during the first quarter; all earthquakes were in the crystalline basement.

The next random event occurred on March $14^{\text {th }}$ in the Cold Creek syncline near the 'horn' of the Yakima River (the abrupt bend at it's northern most point on Figure 4.1). This event was deep and is not near any known geologic structure.

A small event (approximately $0 \mathrm{M}_{\mathrm{c}}$ ) occurred on March $19^{\text {th }}$ in the crystalline basement beneath the three Coyote Rapids swarm area events that occurred this quarter (Section 4.5.2.3.3). Other deep earthquakes have occurred here in the past. If this pattern continues, this earthquake may be reclassified as a swarm event in the future. 
Three small events (approximately $0 \mathrm{Mc}$ ) occurred under Yakima Ridge in the crystalline basement. The first one occurred on March $20^{\text {th }}$ and the next two occurred on March $21^{\text {st }}$. No previous events have been recorded here in the past.

The final random event for the second quarter occurred on March $30^{\text {th }}$ near Ringold Coulee, which is east of Gable Mountain. This event was very small (approximately $0 \mathrm{M}_{\mathrm{c}}$ ) and was located in the crystalline basement. 


\subsection{Strong Motion Accelerometer Operations}

The Hanford SMA network has been in continuous operation since November 20, 1998. The nominal threshold used in the SMA network is $0.001 \mathrm{~g}$ in order to provide ground motion for smaller, nondamaging earthquakes that can be useful in estimating the ground motion expected from larger earthquakes, and to confirm correct operation of the instruments by analyzing the smaller-amplitude triggers (see Section 2.2).

\subsection{Second Quarter of FY 2003 Triggers of the Hanford SMA Network}

The Hanford strong motion accelerometer network was not triggered by any seismic event during the second quarter of FY 2003. 


\subsection{Capabilities in the Event of a Significant Earthquake}

The SMA network was designed to provide ground motion data in areas at the Hanford Site that have high densities of people and/or facilities containing hazardous materials in order to insure the Hanford Site is in compliance with DOE Order 420.1, "Facility Safety." The network also allows Hanford Seismic Monitoring to support Hanford Site emergency services organizations in complying with DOE Order G 420.1-1, Section 4.7, "Emergency Preparedness and Emergency Communications," by providing area ground motion data in the event of an earthquake on the Hanford Site. This section summarizes the capabilities of the Seismic Monitoring Team in the event of an earthquake at Hanford.

\subsection{Use of the SMA Network in the Event of an Earthquake}

Historically, only a few facilities at the Hanford Site had instruments to provide data on peak ground accelerations or any type of ground motion. The present SMA instruments were located so that if an earthquake occurred, ground motion data would be readily available to assess the damage at the 100-K Area, the 200 East and West Areas, the 300 and 400 Area facilities, which have the greatest concentration of people and also contain hazardous materials (Moore and Reidel 1996).

Many facilities at the Hanford Site have undergone various degrees of seismic analysis either during design or during re-qualification. Although the seismic design of a building may be known, when an earthquake is "felt" in a facility on the Hanford Site, a determination must be made as to the extent of damage before it can be reoccupied and the systems restarted. A felt earthquake may not cause any significant damage to a building but, without adequate characterization of the ground motion, initial determination of the building's possibility of having damage may be impossible.

In the event of an earthquake such as the 2001 Nisqually earthquake, building managers, emergency directors, and engineers can obtain ground motion data recorded by the SMA network from the Seismic Monitoring Team in the Sigma V Building. This is done through the Hanford Site Emergency Services Organization. Normal hours of operation for the PNNL Seismic Monitoring Project are between 6 a.m. and 4:30 p.m., Monday through Friday. If a SMA is triggered, the Seismic Monitoring Team will download events that were recorded and determine the peak ground accelerations. This information is then passed on to Hanford Emergency Services personnel where the facility engineers can use the data to determine if the ground motion exceeded, is equal to, or is less than the building design. This, along with assessments from trained engineers, allows the facility manager to make a rapid and cost-effective determination on whether a building is safe to re-occupy or should not be used until it has been inspected in more detail. Buildings that have designs exceeding the recorded ground motion could be put back into service very quickly; buildings with designs that are very close to or less than measured ground motion could be given priority for onsite damage inspections. 


\subsection{References}

Campbell, N. P. 1989. "Structural and stratigraphic interpretation of rocks under the Yakima fold belt, Columbia Basin, based on recent surface mapping and well data." In S. P. Reidel and P. R. Hooper (eds.), Volcanism and Tectonism in the Columbia River Flood-Basalt Province Geological Society of America Special Paper 239, pp. 209-222.

Crosson, R. S. 1972. Small Earthquakes, Structure and Tectonics of the Puget Sound Region. Bulletin of the Seismological Society of America, 62(5):1133-1171.

DOE. 1988. Site Characterization Plan for the Reference Location, Hanford, Washington-Consultation Draft. Report DOE/RW-0164, Vol. 1, U.S. Department of Energy, Washington, D.C.

Fenneman, N. M. 1931. Physiography of western United States. McGraw-Hill, 534 p.

Geomatrix. 1996. Probabilistic Seismic Hazard Analysis, DOE Hanford Site, Washington. WHC-SDW236A-TI-002, Rev. 1, Westinghouse Hanford Company, Richland, Washington.

Moore, C. and S. P. Reidel. 1996. Hanford Site Seismic Monitoring Instrumentation Plan. WHC-SDGN-ER-30036, Westinghouse Hanford Company, Richland, Washington.

Reidel, S.P., 1988. Geologic Map of the Saddle Mountains, South-Central Washington. Washington Division of Geology and Earth Resources Geologic Map GM-38.

Reidel, S.P., 1984. The Saddle Mountains-The evolution of an anticline in the Yakima Fold Belt. American Journal of Science, v. 284, no. 8, p. 942-978.

Reidel, S. P. and K. R. Fecht. 1994a. Geologic Map of the Richland 1:100,000 Quadrangle, Washington. Washington Division of Geology and Earth Resources Open File Report 94-8, 21 p., 1 plate.

Reidel, S. P. and K. R. Fecht. 1994b. Geologic Map of the Priest Rapids 1:100,000 Quadrangle, Washington. Washington Division of Geology and Earth Resources Open File Report 94-13, 22 p., 1 plate.

Reidel, S. P. and P. R. Hooper (eds.). 1989. Volcanism and Tectonism in the Columbia River FloodBasalt Province Geological Society of America Special Paper 239, 386 p.

Reidel, S. P., N. P. Campbell, K. R. Fecht, and K. A. Lindsey. 1994. "Late Cenozoic Structure and Stratigraphy of South-Central Washington.” In E. Cheney and R. Lasmanis (eds.), Regional Geology of Washington State, Washington Division of Geology and Earth Resources Bulletin 80, pp. 159-180, Olympia, Washington. 
Reidel, S. P., K. R. Fecht, M. C. Hagood, and T. L. Tolan. 1989. "Geologic Development of the Central Columbia Plateau." In S. P. Reidel and P. R. Hooper (eds.), Volcanism and Tectonism in the Columbia River Flood-Basalt Province Geological Society of America Special Paper 239, pp. 247-264.

Richter, C. F. 1958. Elementary Seismology, W. H. Freeman and Company, p. 768.

Rohay, A. C., D. W. Glover, and S. D. Malone. 1985. Time-Term Analysis of Upper Crustal Structure in the Columbia Basin, Washington. RHO-BW-SA-435 P, Rockwell Hanford Operations, Richland, Washington. 


\section{Distribution}

No. of

\section{Copies}

\section{OFFSITE}

G. Crawford

Earthquake Program Manager

Washington Emergency Management Division

Building 20, M/S: TA-20

Camp Murray, WA 98430-5122

Jeffery Kimball

NA-53/Germantown Building

U.S. Department of Energy

1000 Independence Ave. SW

Washington, D.C. 20585-1290

S. Lilligren

Nez Perce Tribe

P.O. Box 365

Lapwai, ID 83540

J. Litehiser

Bechtel National, Inc.

P.O. Box 193965

San Francisco, CA 94119-3965

T. L. Nielsen

Kennewick General Hospital

P.O. Box 6128

Kennewick, WA 99336

Paul Rizzo

105 Mall Boulevard

Monroeville, PA 15146
No. of

Copies

3 Oregon Department of Geology and Mineral Industries

Suite 965, 800 NE Oregon Street \#28

Portland, OR 97232

ATTN: J. Beaulieu

Library

I. Madin

N. Rasmussen

3140 Ravenshoe Drive

Las Vegas, NV 89134

W. Riggsby

1216 W. Kennewick Avenue

Kennewick, WA 99336

M. Stickney

Montana Tech University

Earthquake Studies Office

Butte, MT 59701

A. Tallman 1940 Quail Court

West Richland, WA 99353

5 University of Washington

Geophysics Program

P.O. Box 351650

Seattle, WA 98195-1650

ATTN: R. Crosson

R. Ludwin

S. Malone

A. Qamar

R. Steele

Distr.1 
No. of

Copies

2 University of Washington

U.S. Geological Survey

P.O. Box 351650

Seattle, WA 98195

ATTN: C. Weaver

T. Yelin

2 U.S. Geological Survey

Mail Stop 977

345 Middlefield Road

Menlo Park, CA 94025

ATTN: H. Stenner

T. Brocher

U.S. Fish and Wildlife Service

3250 Port of Benton Boulevard

Richland, WA 99352

4 Washington Division of Geology and Earth Resources

P.O. Box 47007

Olympia, WA 98504-7007

ATTN: R. F. Teissere

C. Manson

S. Palmer

T. Walsh

Washington State University

Department of Geology

P.O. Box 643420

Pullman, WA 99164-2812

I. G. Wong

Woodward-Clyde Federal Services

500-12 ${ }^{\text {th }}$ Street, Suite 200

Oakland, CA 94607-4010

J. Zollweg

Boise State University

Department of Geosciences

Boise, ID 83725
No. of

Copies

ONSITE

8 DOE Richland Operations Office

K. L. Flynn A6-35

M. J. Furman A6-38

R. D. Hildebrand A6-38

L.F. Miller H6-60

M. R. Moreno A5-55

J. G. Morse A6-38

M. L. Talbot A6-35

K. M. Thompson A6-38

3 Bechtel Hanford, Inc.
V. J. Cueno
$\mathrm{H} 0-18$
K. R. Fecht
$\mathrm{H} 0-02$
P. J. Mackey
$\mathrm{H} 0-13$

8 CH2M HILL Hanford Group, Inc.

D. D. Bachland $\quad$ S7-86

S. M. Faulk S7-86

J. R. Freeman-Pollard S0-11

D. T. Heimberger R2-11

A. J. Knepp E6-35

F. M. Mann E6-35

R. R. Thompson H6-22

J. J. Zach R1-49

Duratek Federal Services Hanford

R. T. Wilde E6-35

Distr.2 
No. of

Copies

8 Fluor Hanford, Inc.

D. A. Arrigoni

B. R. Bowman

M. E. Brown

J. T. Curtis

S. A. Fargo

T. P. Morales

R. Whitehurst II

M. I. Wood

Stoller

S. Sobczyk

Numatec Hanford Corporation

T. J. Conrads

R3-73

N2-40

N2-56

A3-05

B3-15

H8-60

A3-05

X3-78

H8-44

B2-62
No. of

Copies

Washington State Department of Ecology

J. Caggiano

B5-18

12 Pacific Northwest National Laboratory

M. V. Berriochoa

K9-56

J. S. Fruchter

K6-96

D. C. Hartshorn

K6-81

D. G. Horton

K6-81

W. J. Martin

K6-81

B. D. Moon

K9-55

P. E. Moore

$\mathrm{P} 7-63$

S. P. Reidel

K6-81

A. C. Rohay

K6-81

M. M. Valenta

K6-81

Hanford Technical Library (2)

P8-55

2 Waste Management Federal Services of Hanford, Inc.

D. A. Conners

T3-28

M. T. York

T3-06 